University of Rhode Island

DigitalCommons@URI

Open Access Master's Theses

2017

\title{
The Paid Vote: America's Neutrality During the Greek War for Independence
}

Jared Jacavone

University of Rhode Island, jared_jacavone@uri.edu

Follow this and additional works at: https://digitalcommons.uri.edu/theses

\section{Recommended Citation}

Jacavone, Jared, "The Paid Vote: America's Neutrality During the Greek War for Independence" (2017). Open Access Master's Theses. Paper 1011.

https://digitalcommons.uri.edu/theses/1011

This Thesis is brought to you for free and open access by DigitalCommons@URI. It has been accepted for inclusion in Open Access Master's Theses by an authorized administrator of DigitalCommons@URI. For more information, please contact digitalcommons-group@uri.edu. 
THE PAID VOTE: AMERICA'S NEUTRALITY

DURING THE GREEK WAR FOR INDEPENDENCE

BY

JARED JACAVONE

A THESIS SUBMITTED IN PARTIAL FULFILLMENT OF THE

REQUIREMENTS FOR THE DEGREE OF

MASTER OF ARTS

IN

HISTORY

UNIVERSITY OF RHODE ISLAND

2017 


\section{MASTER OF ARTS IN HISTORY THESIS \\ OF \\ JARED JACAVONE}

APPROVED:

Thesis Committee:

Major Professor $\_\frac{\text { Rod Mather }}{-\frac{\text { Yan Ma }}{\text { Bridget Buxton }}}$
$\frac{\text { Nasser H. Zawia }}{\text { DEAN OF THE GRADUATE SCHOOL }}$

UNIVERSITY OF RHODE ISLAND

2017 


\begin{abstract}
:
This thesis will center upon the level of involvement Americans had in the Greek War of Independence from 1821-1829 despite remaining neutral during the conflict. Primarily focusing on the contributions of individuals and organizations, the thesis will discuss the political actions that occurred to support the Greeks, and how different American citizens contributed to the conflict. In addition, the text will explore why the United States did not formally give support to the war despite the philhellenism of prominent political figures, such as Thomas Jefferson and Daniel Webster. Groups and individuals in the Boston area had competing interests that both helped and hindered aid to the Greek cause. Trade interests with China and Turkey motivated Bostonian elites to press Congress to stay out of the conflict. These same forces, however, along with political likening to the cause, fueled individual efforts that provided private American aid to the Greek Independence Movement.
\end{abstract}




\section{$\underline{\text { Acknowledgements }}$}

For their assistance and hospitality I would like to thank the following libraries and archives: University of Rhode Island Library, Massachusetts Historical Society, Baker Library at the Harvard Business School, Olin and Uris Libraries at Cornell University, the Public Library of Brookline, Brown University Libraries, American Antiquarian Society, The National Archives in Waltham, MA, Phillips Memorial Library at Providence College, Medford Public Library, and Providence Public Library.

I would also like to extend a special thanks to these librarians and public historians for their friendliness and help in accessing their library/archive's collections: Ben Johnson and Melissa Murphy of the Baker Library at the Harvard Business School, Rob Kotaska and Anthony J. Cosgrove of the Olin and Uris Libraries at Cornell University, Sabina Beauchard of the Massachusetts Historical Society, Krista Barresi of the Public Library of Brookline, and Don Boudreau of the American Antiquarian Society. Additionally, I would like to thank the committee members that have taken the time to review this work: Dr. Yan Ma, Dr. Bridget Buxton, and Dr. Kristine Bovy. Lastly, I would like to extend a sincere thanks to my thesis advisor, Dr. Rod Mather, not only did you teach me about the past, but also you guided me through the process of writing this work and made me a better historian. 


\section{$\underline{\text { Dedication }}$}

For Mom and Dad, who inspired me to pursue my dreams, And for Alexis, who helps me build my dreams. 


\section{Preface}

As a student of history with a deep interest in the Classics, I always wanted to explore a topic that related to the Ancient World. In my prospectus class with Dr. Mather, I was given the task of exploring a topic related to the history of Massachusetts and Rhode Island, as well as "diving deep" into maritime trade. Approaching the subject as someone who specializes in a completely different era of history, I reflected on the topics where the Classics intersected with American Maritime history. One of the subjects that came to mind was Neo-Classical America, and the founding ideals of America's government.

I recalled the excitement of one of my undergraduate professors, Dr. John Lawless, as he explained the way early $19^{\text {th }}$ century Americans held onto the Classics, and how our Founding Fathers, most prominently Thomas Jefferson, entrenched themselves in the literature from two millennia ago. As he explained, "Ante Bellum America was the golden age of Neo-Classical thought... not only did our ancestors read and understand dead tongues, but also they adopted what they learned and put it into political action." He then went on to briefly mention the American Revolution and the Greek War for Independence, stating, "It was the first time the American public rallied together for a foreign cause, and it was because of their shared love of Classical writings that the people of the Early Republic came together on this issue."

When my class with Dr. Lawless came to an end, I felt that my understanding of America's involvement in the Greek War for Independence was incomplete, and wanted to know why the United States refused to enter the war, despite such public support. 
Thus, when given the opportunity in my graduate-level prospectus class, I decided to finally answer this conundrum for myself. At first I was satisfied with what I found in the available academic literature, as there were a multitude of accounts of individuals participating in the conflict, and entire articles dedicated to what Americans did to help the Greek cause. Yet I soon discovered that while the topic had been widely explored, the explanations for why America stayed out of the conflict seemed to just accept the Monroe Doctrine as the central reason for staying out of the conflict-no historian seemed interested in discussing how or why the government just accepted this policy. This all changed when I came across an article by Michael Chapman, for, unlike the other historians I read, he suggested that something did not seem right about America's neutrality during this war, and instead proposed an economic explanation for America's refusal to participate. Pointing to questionable political connections and America's involvement in the Chinese opium trade, Chapman made me question everything that I had read up to that point. The topic had shifted from a societal study to a political and economic subject, I focused upon the wealth and connections of the Boston merchant, Col. Thomas H. Perkins.

This pushed me to travel to archives across the region and to ask a new series of questions, such as, who was Thomas H. Perkins? Why did he know John Quincy Adams? Who else did he know? Why did he not like the Greek cause? At this point, the nature of my research had shifted from a simple historical exploration of a topic to something exciting and almost mysterious. Never before had I encountered something so challenging to the traditional historical narrative of a subject. It was Carl Seaburg and Stanley Patersons' biography of Col. Thomas Perkins that brought all of my evidence, 
both primary and secondary, together. After months of investigation and reading, I could now present a case on what I had studied and, perhaps, stimulate questions about our traditional understanding of American history at the time of Greek Independence.

With the guidance of my advisor, Dr. Rod Mather, and months of research and writing, I present to the reader my final insights. As my freshman historiography professor, Dr. Constance Rousseau, taught me, nothing can ever be certain in understanding what happened in the past, but, as historians, it is our job to find some truth and remind the world to question our traditional understanding of the past. I hope my investigation into this topic can spark true academic debate on the subject, and encourage us all to investigate history with speculative eyes. As my undergraduate mentor, Dr. Fred Drogula, taught me, it is only through the primary sources and our prudent investigation of them that we can find some truth about the past. This work attempts to hold onto this value, and use the evidence that is actually out there to construct an understanding of the past. 


\section{$\underline{\text { Table of Contents }}$}

Abstract..................................................................

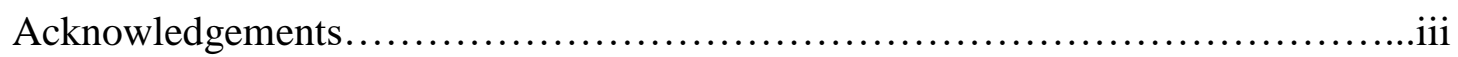

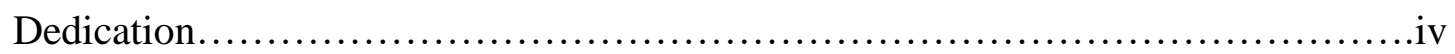

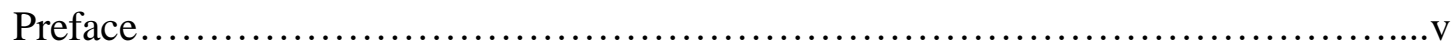

Table of Contents........................................................ viii

Introduction and Historiography.........................................

Part I: The Philosophical Foundations..................................... 13

Part II: Sacrifices for the Cause and the Issue with the Monroe Doctrine..............37

Part III: Perkins and the Boston Oligarchy.................................56

Conclusion.......................................................... 95

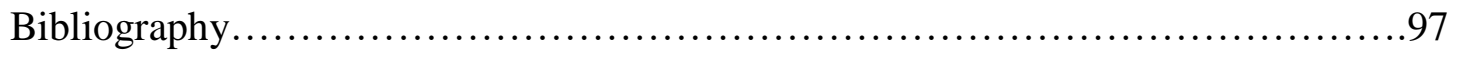

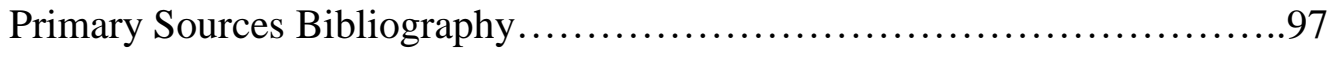

Secondary Sources Bibliography................................... 100 


\section{Introduction and Historiography:}

The Early American Republic faced several challenges as its government attempted to uphold revolutionary and republican values while navigating diplomacy with former allies and enemies. Tested by the War of 1812, the economic panics of 1807 and 1817, and upholding Washington's recommendation for neutrality, the young Republic discovered that foreign affairs challenged the very foundation of America's identity. Since the country's early economy was strained, its leaders felt pressure to compromise Revolutionary values for financial prosperity. The Greek War for Independence proved to be one of these great obstacles, and required leaders, as well as businessmen, to choose between a cause they believed in and economic prosperity.

Popular support for joining the international community to defend the Greek people spoke to the nation's ideologies of Classical Liberalism, Classical Republicanism, and Christian Brotherhood yet the government of the United States ultimately refrained from joining the conflict. This restraint might be explained by the spreading notion that the nation's economic stability might become uncertain if the young nation became involved with the Greek conflict. Individuals, as well as communities, felt increasingly vulnerable to possible commercial ambiguity. Thus, in the early days of the American Republic, it was only logical for the United States government to secure its economic bearings before engaging into serious military and diplomatic upheavals.

Despite the clear economic concerns, the more popular explanations for why the United States stayed out of the conflict have centered upon diplomatic and political considerations. One of the most prevalent arguments is that John Quincy 
Adams did not want to be allied with the British immediately after the War of 1812, and United States did not want the powers of Europe interfering in Latin American and United States affairs. While these explanations are true and were the official policies of the United States government at the time, it seems more likely that economic factors heavily influenced the ultimate decision to not intervene. The young Republic was recovering from war and much of its economy depended upon trade. At this time, Colonel Thomas H. Perkins, a wealthy Boston merchant involved in the Canton trade and opium market, and other prominent figures involved in commerce were attempting to expand their wealth and wanted a stable economy to do so. The political maneuverings of Col. Thomas H. Perkins and his economic influence on the Boston community suggest that the real reason for United States' neutrality was not diplomatic concerns, but rather economic interests and backroom deals. By examining letters, public papers, and speeches from the time, it is evident that American neutrality during the Greek War for Independence was brought on by individual interests, political connections, and concern over the country's maritime economy.

The sources and scholars that have dealt with this topic have explored several different aspects of why America remained neutral from the conflict. While much of the work has focused primarily upon diplomatic and political reasoning for neutrality, the most significant and recent revelation in scholarship on the subject has looked to economic factors as the main cause of the neutrality. Therefore, the extent of private involvement and influence in the government's decision to not join the Greek War for Independence can be illuminated by secondary sources. More 
specifically, it is through an examination of scholarly work that deals directly with this subject, the historical literature that focuses upon the philosophical thinking of Ante Bellum America, and the lives of prominent figures of this time that this influence can be understood.

Studies of American involvement in the Greek War for Independence can be divided into three or four different schools of thought. One perspective focuses on a political and diplomatic reasoning for American neutrality, and tends to focus on President John Quincy Adams' own political philosophy for the refrainment. ${ }^{1}$ Another posits that Adams reacted to this situation not just out of his own political and diplomatic philosophy, but also because he wanted to distance himself from the controversial Federalist Party. ${ }^{2}$ A third perspective insists that economics and commerce were the primary motivation for non-involvement. The economic reasoning did not necessarily focus on the general welfare of the country, but rather upon certain individuals that held substantial financial investment in both the United States and Turkey. ${ }^{3}$ The last school of thought takes on a more post-modern approach that centers upon the ways individual Americans were involved in the conflict. This view does not directly address the discussion of economics versus politics, but rather focuses on how Americans contributed to the conflict. The reasons why the government did not formally get involved are ignored. If authors that subscribe to this perspective do take a side, they generally

\footnotetext{
${ }^{1}$ Angelo Repousis, "'The Cause of the Greeks:' Philadelphia and the Greek War for Independence, 1821-1828," The Pennsylvania Magazine of History and Biography 123, no. 4 (October 1999): 333-363.

${ }^{2}$ Lawrence S. Kaplan, "The Monroe Doctrine and the Truman Doctrine: The Case of Greece," Journal of the Early Republic 13, no. 1 (Spring 1993): 1-21.

${ }^{3}$ Michael E. Chapman, "Pragmatic, ad hoc Foreign-Policy Making of the Early Republic: Thomas H. Perkins's Boston-Smyrna-Canton Opium Model and Congressional Rejection of Aid for Greek Independence,” International History Review 35, no. 3 (2013): 449-464.
} 
indicate that the Monroe Doctrine and politics prevented the government from being formally involved. ${ }^{4}$

What is most interesting about the different perspectives on this topic is the universal agreement on a handful of different ideas and concepts. First, all authors seem to agree that there was massive popular support for the Greek Revolution and that Americans held certain assumptions about the innocence of the Greek people. Second, all historians agree that the justification and interest for support of the Greek War for Independence came from America's admiration of the "Ancient Past," a common Christian heritage with the Greeks, and America's view that the Greeks were also fighting for the same revolutionary tenants as the Americans had. In addition, Americans saw this as an important opportunity to be the model Republic in the world. If Americans supported the Greek cause, then the nation would be passing on the revolutionary spirit and acting as a leader for other emerging republics. Finally, all sources agree that John Quincy Adams did not want to get directly involved in Greece, irrespective of whether there were good diplomatic and/or economic reasons. The points that Adams used in his defense of non-involvement were a continuation of Washington's appeal for isolationism and James Monroe's diplomatic precedence with the Monroe Doctrine.

The school of thought that focuses the most on these common themes is the postmodernist group that explores American interest in the conflict, and the contributions of individuals. One author from this school is Edward M. Earle; his work, which dates back to 1927 , is one of the earliest academic accounts on this topic. Earle argues that support of the Greek War for Independence was very popular with the American people; Greek

\footnotetext{
${ }^{4}$ Edward Meade Earle, “American Interest in the Greek Cause, 1821-1827," The American Historical Review 33, no. 1 (1927): 44-63.
} 
Committees organizing resources for the war popped up all around the country in cities, such as Boston, New York, and Philadelphia. ${ }^{5}$ The author points to the different individual contributions that helped support the cause. Such contributions included donations, fundraising events, and the donation of space on ships to the Greek Committees for sending supplies to the Greeks. ${ }^{6}$ Aside from the material contributions of individuals, Earle also discusses the personal involvement of individuals in the conflict and demonstrates how important this conflict was in the minds of many Americans. ${ }^{7}$ Earle also discusses in detail the reasons people favored the Greeks and wanted to help them so desperately. Using the Bostonians Edward Everett, the leader of the Greek Committee of Boston and also a United States congressman at the time, and Daniel Webster, a prominent United States senator that was known for his strong support for the Greek cause, as examples Earle explains that Americans supported the war because people admired the Ancient Greeks. Furthermore, he discusses how the Greek Revolution had adopted the revolutionary ideas of America, and how the Greeks were fellow Christians being oppressed by Muslims. This gave Americans a sense of brotherhood with the Greek people. ${ }^{8}$ Earle discusses the Monroe Doctrine, but only mentions the foreign policy to justify United States neutrality during the conflict. ${ }^{9}$ The focus of his paper was the support from individual Americans, not the reasons why America decided to remain neutral.

\footnotetext{
${ }^{5}$ Edward Meade Earle, "American Interest in the Greek Cause, 1821-1827," The American Historical Review 33, no. 1 (1927): 50.

${ }^{6}$ Ibid., 51.

${ }^{7}$ Ibid., 54-55.

${ }^{8}$ Ibid., 44-49.

${ }^{9}$ Ibid., 49.
} 
Andrew Horton's text on Jefferson and Korais further examines the reason why Americans were interested in the conflict but also how the influence of these two men effected public perception of the war. Horton argues that the long-term relationship between Thomas Jefferson and Adamantios Korais, exemplified by extensive correspondence between the two men, helped plant the seed of liberty and revolution in each other's country. Through the comparison and exchange of ideas between the American culture and Greek history, each civilization mutually supported and inspired the other. Specifically, Korais was inspired by the American struggle and liberalism while Jefferson and his peers were influenced by the Classics. The discussion of Ancient History and the views of early-modern political philosophers, such as Rousseau and Locke, brought these prominent figures together intellectually and each inspired the other's cause ${ }^{10}$ Horton's text, while brief in its discussion, demonstrates the philosophical and cultural commonalities between Greece and America. It identifies the reasons for America's popular support of the conflict and serves as an important academic source that many scholars of this field draw upon.

Earl and Horton serve as the basic foundation of the subject; their articles are the first to identify the historical sources and explain why Americans were interested in the Greek War for Independence. In addition, both serve as the launching point for the economic and political perspectives of this field that one sees in academia today.

The first perspective that emerged after these foundational studies of the subject centered upon the political and diplomatic reasons as to why America did not formally become involved in Greek Independence. For a lack of better terms, these historians can

\footnotetext{
${ }^{10}$ Andrew S. Horton, "Jefferson and Korais: The American Revolution and the Greek Constitution," Comparative Literature Studies 13, no. 4 (December 1976): 323-324.
} 
be viewed as the Monrovian ${ }^{11}$ and Anti-Federalist schools of thought. Lawrence Kaplan best represents the political argument (Anti-Federalist view) for why America decided to not become involved. Pointing to John Quincy Adams, Kaplan explains that becoming involved in the conflict would have been a bad move for America and Adams politically. If the British were to become involved in Greece, and Americans were fighting right along side them, it would imply that Adams was a Federalist and that Adams was willing to forget the War of 1812. If Adams was to involve the United States on the side of the British, then it would be seen as an act of treason because the Federalists wished to secede from the United States during the War of 1812 and give aid to the British. ${ }^{12}$ Kaplan also explains that Adams thought it was America's duty to remain independent from European conflicts even if an event seemed to echo the American Revolution. To reinforce this point, Kaplan points to the Monroe Doctrine as Adams' reasoning for staying out of the conflict entirely. Adams did not want to risk being entangled in European conflicts and he wanted to keep Europe out of Latin America. Going to war in Greece would give European powers license to interfere in the Americas. While Kaplan helps exemplify the tenants of this perspective, he draws much of his arguments from Ernest May, and the focus of Kaplan's article is a comparative analysis of U.S. relations with Greece between the 1820s and 1947.

Angelo Repousis builds off of Kaplan's work by re-evaluating the reasons why America did not get involved in the Greek War for Independence. Repousis echoes the

\footnotetext{
${ }^{11}$ Monrovian is the historical perspective that reasons the United States stayed out of the Greek War for Independence because of the Monroe Doctrine's commitment to staying out of European affairs. This view draws upon diplomatic commitments and political ties for its justification.

${ }^{12}$ Lawrence S. Kaplan, "The Monroe Doctrine and the Truman Doctrine: The Case of Greece," Journal of the Early Republic 13, no. 1 (Spring 1993): 2-3.
} 
same understanding of the Monroe Doctrine as Kaplan but also demonstrates that despite the reluctance to commit the United States to a European conflict there was a real urge to be involved in some way. In fact, James Monroe approached Congress, and the public at large, pleading for non-intervention with the military but also encouraging relief efforts to be made and supplies to be sent to the Greeks. ${ }^{13}$ Furthermore, Repousis argues that Adams feared getting involved in a foreign conflict unrelated to Europe, specifically one that involved Egypt and other African states. ${ }^{14}$ While Repousis certainly takes the diplomatic and political perspective on American neutrality, he does touch upon an important point in regard to trade. While he does not use economics as a main argument, he does open up the door to another reason why America did not get involved. Specifically, some businessmen, particularly Boston merchants, were nervous about the repercussions of a war with Turkey on their companies; they were even nervous about non-combative assistance to the Greeks. ${ }^{15}$ The risk of upsetting the Ottoman Empire raised the concern that trade in the Mediterranean Sea could be diminished, and Muslim pirates and the Barbary States would become emboldened and be far more active in attacking American vessels since they were allied with the Ottoman Empire. Adding this to the diplomatic reasons, Repousis takes a position that rests upon mostly political reasoning and a certain degree of economic protection.

From this argument, one can see the foundation of an economic perspective in this area of study. The first to take a mostly economic perspective is Michael Chapman. Chapman proposes that merchants were nervous about the economic repercussions of the

${ }^{13}$ Angelo Repousis, "'The Cause of the Greeks:' Philadelphia and the Greek War for Independence, 1821-1828," The Pennsylvania Magazine of History and Biography 123, no. 4 (October 1999): 338-339.

${ }^{14}$ Ibid.

${ }^{15}$ Ibid., 340. 
United States opposing Ottoman policy as it would certainly result in restricted access to the Mediterranean and the potential loss of profit. Chapman suggests that these merchants utilized their financial resources to influence politicians and protect their ability to travel the seas. By way of example, Chapman discusses how profitable Col. Thomas $\mathrm{H}$. Perkins' China trade through Turkey was, estimating that it generated over \$1 million ( $\$ 84$ million in today’s economy) annually in profit from Perkins' company alone. ${ }^{16} \mathrm{He}$ further argues that the political reasons for neutrality were cosmetic, and that even the supporters of Greek Independence ended up being convinced by the merchants' argument. Chapman demonstrates this sudden shift by discussing how Everett, an ardent supporter of the Greek cause, did not protest or try to push harder for the conflict after the vote in the United States Congress was tabled. ${ }^{17}$ Chapman further supports his argument by discussing the relationships between the different Bostonians (Perkins, Adams, Everett) involved in the ultimate decision with Col. Thomas H. Perkins. Thereby proving that aversion to the war was caused by economic worries rather than diplomatic and political resolve.

Other scholars that specialize in the Early American Republic provide additional evidence that provides a context for the events surrounding the Greek War for Independence. While these authors cannot be attributed to a particular and, at best, most closely resemble the positions of Earl and Horton. Literature on the lives of important individuals and the culture of the Early Republic contribute the most to this area of study. In particular, the Merchant Prince of Boston, by Carl Seaburg and Stanley Patterson,

\footnotetext{
${ }^{16}$ Michael E. Chapman, "Pragmatic, ad hoc Foreign-Policy Making of the Early Republic: Thomas H. Perkins's Boston-Smyrna-Canton Opium Model and Congressional Rejection of Aid for Greek Independence," International History Review 35, no. 3 (2013): 453-454.

${ }^{17}$ Ibid., 452.
} 
examines the life of Col. Thomas H. Perkins. The authors use letters, speeches, journals, and correspondences to characterize not only the role and influence of Perkins on the Bostonian and New England economy, but also his stake and participation in the Massachusetts political arena. By the same token, the book Israel Thorndike: Federalist Financier, by J.D. Forbes, provides a similar biographical sketch, and hints at the interconnectedness of the elites of Boston's merchant class. These biographical works act as valuable resources in their own right, and Chapman and others of his school of thought focused on the resources available in these works.

Carl J. Richard specializes in Neo-Classical American study and has authored several works that are foundational to the study of this period in American history. Richard's Founders and the Classics: Greece, Rome, and the American Enlightenment and The Golden Age of the Classics in America provide important insight into the Ante Bellum period's cultural lifestyle. The Founders and the Classics specifically examines the Classical scholarship of America's Founding Fathers, and chronicles their use and consumption of these works in their everyday life. Furthermore, Richard also discusses the influence of these ancient texts upon the Founding Fathers when it came to developing the Constitution of the United States. The Golden Age, by contrast, focuses less upon the Classical scholarship of the founders and more upon the emulation of antiquity in the everyday life of Ante Bellum America. Through the examination of pastoralism, democracy, slavery, and nationalism, Richard's work explains the way in which Americans placed ancient ideas into the national fabric. Furthermore, Richard characterizes the study of Classics as a focus for American elites and the middle class, as 
well as a main tenant of American farmers (especially in the South) ${ }^{18}$ Both of Richard's texts provide important commentary on the culture and identity of the Early American Republic, and each makes the case for an America that tied itself very closely to the history of Ancient Greece and Rome. Each school of thought, especially the postmodernist school championed by Earle and Horton, draws upon the ideas and historical trends that are expressed in Richard's works. Hence does Richard's work best explain the context of this period, and demonstrates why the United States government would show preference to the Greek Independence struggle over other revolutionary movements in other nations such as Serbia.

This thesis sides with the economic perspective on the events surrounding American neutrality and extends the arguments first developed by Chapman. Contributing to the idea that individual private parties influenced political decisionmaking on the federal level for financial interest, this work adds to Chapman's view and further sophisticates the economic school of thought. Unlike Chapman, however, this thesis emphasizes the idea that local politics, business relationships, personal associations, and political affiliations gave prominent individuals the ability to bend national politicians to their own personal agenda. Through the examination of letters, biographies, and various first-hand accounts, the influence of private individuals over national figures is made clear.

Despite the overwhelming popular support for the Greek people, because of the perceived philosophical and cultural similarity to American society, the influence of wealthy individuals not only smothered the democratic voice of the country, but also

${ }^{18}$ Carl J. Richard, The Golden Age of the Classics in America (Cambridge, MA: Harvard University Press, 2009), 85-88. 
spoke on the nation's behalf in determining American foreign policy for the rest of the 19th century. Shining a light upon the business practices and dealings of the prominent merchants Thomas H. Perkins and Israel Thorndike, one can see just how influential and invested these men were in American politics. These individuals built political networks, controlled the financial and political fates of entire states, and expanded their business empires to halfway across the world. Through money and political puppet mastery, the Boston mercantile elites tamed several national figures and utilized the positions of these politicians to protect their own investments. Thus, it was not truly in the interest of the nation that the American government stayed away from Greece and declared a foreign policy of neutrality through the Monroe Doctrine for the rest of the $19^{\text {th }}$ century. These actions, rather, benefitted the financial elites that dominated New English shipping economy as well as those Americans involved in the Chinese Opium Trade. 


\section{Part I: The Philosophical Foundations}

In many cases, historical actors have some sort of motive and cultural perception of the world that inspires their actions. While economic motives have been a powerful force, it is far more common to see cultural values and beliefs generally drive human action and policy. It is for this reason that America's treatment of the Greek War for Independence was so controversial. Not only was it a matter of favoring one revolution over another, but also it was a philosophical crisis rooted in the very founding ideals of that nation. The foreign policy of the United States contradicted both the identity of the nation and the will of the American people because the American people identified with the Greeks and the Greek War for Independence reflected many of the same values Americans fought for in the American Revolution. In a way, turning away from the Greek cause was the same as rejecting the United States Constitution and the ideals expressed during the American Revolution.

During the Early American Republic, the influence and spirit of the American Revolution was still very much alive and Americans identified themselves with Classicism, Classical Liberalism, and Christianity. ${ }^{19}$ The Founding Fathers had constructed the U.S. Constitution with an eye towards Classical Liberalism and ancient political theory, and political discourse relied upon references to Classical ideas. American farmers (especially those in the American South) emulated the Classics through ideas of Roman Pastoralism, and large sections of the American population, although not highly educated, were familiar with Classical references because it was a

\footnotetext{
${ }^{19}$ Angelo Repousis, "'The Cause of the Greeks:' Philadelphia and the Greek War for Independence, 1821-1828," The Pennsylvania Magazine of History and Biography 123, no. 4 (October 1999): 333-334.
} 
part of daily culture. Therefore, the fact that the American government refused to formally enter the Greek War for Independence, either as a belligerent nation or as a formal economic and diplomatic sponsor, was counter to both the will and identity of the American people.

To understand how fundamental Classical ideas were to the country and the population, one must look to both American education and the foundations of the American government itself. According to Carl J. Richard, the Founding Fathers, and most well-to-do people in the late $18^{\text {th }}$ to early $19^{\text {th }}$ centuries, were brought up with a "Classical Education." From the age of eight through college, all educated students were trained in Greek and Latin, and these students not only read the histories of Livy, Plutarch, Xenophon, Virgil, Cicero, and other ancient authors, but also read these works in their original language. ${ }^{20}$ Dedicating several hours a day to translation of Latin and Greek, the educated became highly skilled in classical languages. It was even a part of the curriculum to translate long sections of the New Testament from Koine Greek into Latin and/or English. ${ }^{21}$ The Classics, therefore, took on a special meaning to the Founders and other educated Americans. Not only was it the foundation of their education in law, grammar, philosophy, history, and ethics, but also it was intimately tied to Christianity in the classroom.

Knowledge of Classical languages and history was viewed as a necessity for entering the middle class and professional occupations. Reverend James Maury, Thomas Jefferson's teacher, wrote “an Acquaintance with the Languages antiently spoken in Greece and Italy, is necessary, absolutely necessary, for those who wish to make any

\footnotetext{
${ }^{20}$ Carl J. Richard, The Founders and the Classics: Greece, Rome, and the American Enlightenment (Cambridge, MA: Harvard University Press, 1994), 12-14.

${ }^{21}$ Ibid., 13.
} 
reputable Figure in Divinity, Medicine, or Law." ${ }^{22}$ This was not just the view of intellectuals and the wealthy; in fact, the poor and middle income Americans (especially in New England) saw the value of a Classical education as a means of socio-economic advancement. ${ }^{23}$ Thus, familiarity with the Ancient World, even if it was minimal, was commonplace and a sign of economic advancement.

The benefits and influence of a Classical education did not just resonate with the generation of the Founders, but also the Founders themselves shaped American society and encouraged their successors to embrace the Classics. John Adams ensured that his children studied the Classics and made them intimately familiar with history and ancient languages. He even went so far as to encourage his grandchildren to study the Classics. ${ }^{24}$ At the time of Adams' death in 1826, he had created a Greek and Latin Academy in Quincy, Massachusetts. ${ }^{25}$

Thomas Jefferson shared a similar enthusiasm for Classics as the basis for education. For instance, when Jefferson founded the University of Virginia, he made it a requirement that applicants to be intimately familiar with the Classics. This included a significant grasp of ancient works, the ability to translate Latin on sight, and a "thorough knowledge of Euclid. ${ }^{26}$ Other prominent politicians and Founders such as Alexander Hamilton, Aaron Burr, George Washington, Henry Clay, James Monroe, George Wythe, and others had some level of Classical education and encouraged their peers and children

\footnotetext{
${ }^{22}$ Ibid., 18.

${ }^{23}$ Ibid., 20.

${ }^{24}$ Ibid., 33-34.

${ }^{25}$ Ibid., 34.

${ }^{26}$ Ibid., 34.
} 
to embrace ancient works. ${ }^{27}$ Thus, the Classics were a central part of both social and political discourse well into the Ante Bellum period of the United States.

When examining the rhetoric and writings surrounding the Greek conflict at this time, it is easy to see how much the Classics influenced the political discourse. In his address to Congress in January 1824, Daniel Webster made numerous references to the Classics, and he identified with the Ancient Greeks when arguing the case for Greece. Specifically, Webster attributes all of modern civilization to the contributions of the Ancient Greeks and argues that, if it were not for the Greeks, then the American Republic would not exist. ${ }^{28}$ Furthermore, Webster strongly emphasizes that the Classics were a cultural and philosophical part of the nation's very societal foundation and that the conflict in Greece was not just some foreign affair. Webster insisted that it was more by stating "I wish to treat the subject on such grounds, exclusively, as are truly American..."29 This speech was not only evidence that Americans identified with the Greeks through the Classics and enlightenment liberalism, but also Americans viewed the conflict as a historic tribute to a people that helped inspire the American government. In the eyes of Daniel Webster, the Greek War for Independence was an American conflict because it resembled the nation's struggle during the American Revolution and the Greeks held many of the same values that helped found the United States. Aside from these points on the speech's content, Webster's rhetoric also spoke loudly to the education and identity of the audience to which he is speaking. Since Webster was able to

${ }^{27}$ Ibid., 35-36.

${ }^{28}$ Daniel Webster, Mr. Webster's Speech on the Greek Revolution (Boston: Cummings, Hilliard, \& Co. University Press, 1824), 3-5.

${ }^{29}$ Ibid., 5 
speak so freely about the Ancient World and make casual references to ancient writings, the manner and subject of his words alone indicated that the Classics were commonplace. Each Congressman knew exactly what Webster meant when he said "Even the Edifice in which we assemble, these proportioned columns, this ornamented architecture, all remind us that Greece existed, and that we, like the rest of mankind, are greatly in her debts... we... have inherited this obligation from our ancestors, should now attempt to pay it, to those who may seem to have inherited, from their ancestors, a right to receive payment. ${ }^{30}$ The works of ancient authors were so present in the minds of the people of this time that it almost goes without say that each person felt a homage to the ancient past and identified their own government and culture with that of the Ancient Greeks. Thus, the cause of Greece was not only a revolutionary struggle for the same principles that founded America, but it was viewed as an ethical obligation to pay back the ancients by aiding their descendants.

This admiration of Ancient Greece and a desire to help the descendants of Greek heroes was not empty in meaning; the Founding Fathers actively lent advice and maintained active correspondence with the Greek Revolutionaries. Thomas Jefferson was the most influential of the Founders during the Greek struggle. According to Andrew Horton, Jefferson was in contact with Adamontios Korais (Coray is an alternative spelling) during the Greek Revolution. They exchanged ideas that influenced each other's thinking. ${ }^{31}$ Horton also points out that both Korais and Jefferson were, in many respects, close academic peers that exchanged ideas about both Classical Liberalism and Classicism. Both were the same age and both received an education that included selected

\footnotetext{
${ }^{30}$ Ibid., 4.

${ }^{31}$ Andrew S. Horton, "Jefferson and Korais: The American Revolution and the Greek Constitution," Comparative Literature Studies 13, no. 4 (December 1976): 325 and 328.
} 
works from Locke, Hobbes, and Voltaire, as well as ancient texts. ${ }^{32}$ In addition, both men had a deep interest in the study of languages and each was trained for professional occupations with a deep background in the humanities; Korais became a Doctor of Medicine and Jefferson became a lawyer. ${ }^{33}$

Inspired by Jefferson, Korais reached out to the statesman in 1823 for advice on the Revolution and for possible diplomatic aid in helping bring together the Greeks for the conflict. ${ }^{34}$ This willingness to correspond with such a high profile stranger demonstrates an admiration for America's Revolution and a feeling of philosophical fraternity. Jefferson immediately responded, not with what Korais wanted, but with a rather lengthy letter advising the new revolutionary on eventually building his nation. ${ }^{35}$ Using Classical Liberalism and some examples from the American system, Jefferson prescribed a system of government similar to that of a United States state, but adjusted liberalism to the unique identity of Greece. ${ }^{36}$ Interestingly, Jefferson's view of the Modern Greek people was tied very closely to their ancient identity. At the end of Jefferson's letter, one can catch a glimpse of Jefferson perception of the Greek people "rendered to the names of your Homer, your Demosthenes, and the splendid constellation of sages and heroes whose blood is still flowing in your veins." ${ }^{37}$ This exchange demonstrates the same view as Webster; the Ancient World was the foundation of United States, and the United States views the Greek people as the descendants of these ancient people and that the United States should pay homage to them. In addition, there seemed

\footnotetext{
${ }^{32}$ Ibid., 323.

${ }^{33}$ Ibid.

${ }^{34}$ Ibid., 324.

${ }^{35}$ Ibid., 325.

${ }^{36}$ Ibid., 326.

${ }^{37}$ Ibid., 327.
} 
to be this feeling of needing to provide philosophical guidance in classical liberalism by speaking extensively on political theory and prescribing a democratic form of government best suited for the people of Greece.

This sort of philosophical guidance was apparently accepted by the Greeks (at least in the case of Korais). In fact, Korias expressed great gratitude for Jefferson's advice and event sent the former president a copy of Plutarch. These words were not empty in meaning. Korais helped design the Greek Constitution, and he even urged his peers to study Thomas Jefferson and the various political works (including the Constitution and Bill of Rights) produced during the American Revolution. ${ }^{38}$

Horton's analysis of this exchange understates just how intellectually intimate the interchange of ideas were between Korais and Jefferson. At the beginning of one letter, Jefferson not only references the copy of Plutarch he had received from Korais, but also refers to reading Korais' translation of Aristotle's Ethics and how Jefferson utilized a modern Greek dictionary to read Korais' "patriotic" speech to his countrymen. ${ }^{39}$ This sort of academic attention suggests both a real interest on Jefferson's part and a sort of intellectual kinship through both the Classics and Liberalism. Jefferson not only responds to this Greek statesman, whom he has never met, but also becomes familiar with his work. The ancient world becomes a common intellectual playground in which both men share books and history. Jefferson, having advised Korais on government, even suggested the implementation of a classical education system for the Greek Republic. The American leader mentioned this education system in the context of describing the individual state governments of the United States where public education was made

\footnotetext{
${ }^{38}$ Ibid., 327.

${ }^{39}$ Thomas Jefferson to Adamantios Coray, 31 October 1823, in America in Greece: A traditional Policy, ed. David M. Robinson (New York, NY: Anatolia Press, 1948), 41.
} 
available and each student learns history, Latin, and Greek. ${ }^{40}$ Such an association suggests that Jefferson viewed the Classics, not only as a foundational element in education, but also as the foundational element in a Republican society. Jefferson prescribes the Classics and Liberalism to Greece not just for the sake of revolution, but for the goal of creating a self-determined society that has a republic as its form of government. This interest in the conflict from one of America's founders demonstrates an intention to promote the spirit of revolution in another country. Furthermore, Jefferson's attentiveness to explaining classical thought and liberal philosophy suggested an exchange of ideas that, in the American leader's view, aimed to support and encourage a people that the United States itself took inspiration from for its own revolution.

Obviously, Jefferson's letters and Webster's speeches, demonstrate that the ancient classics were a strong influence upon the middle and upper classes of American society. Prominent leaders, elites, and politicians knew their Cicero, Livy, and Herodotus as well as their ancient Greek and Latin. Classics were not only a sign of a modern education, but knowledge of the Classics served as an essential skill for professionals and allowed for socio-economic advancement. It served as an important tool for political discourse and it facilitated conversation for both social and intellectual activities. While it is easy to assume that the Greek and Roman Classics were limited to only the well-to-do, there is strong evidence to suggest that the common man not only understood Classical references and ideas, but the Classics were a part of the everyday experience.

Sereno Edwards Dwight, a pastor and member of the Boston Greek Committee, addressed a crowd in the Park Street Church and the Old South Church in Boston in April of 1824. His speech addressed the Greek War for Independence and made the case for

\footnotetext{
${ }^{40}$ Ibid., 45 and 42.
} 
aiding the Greeks on the grounds of common religion, the revolutionary spirit, and a respect to descendants of the Ancient Greeks. In this speech, Dwight makes casual references the Ancient World and talks about historical concepts in a way that requires the audience to have some familiarity with historical events. For instance, Dwight says, "Fighting alone, at this dreadful disadvantage, amid murders and desolations which have made the world turn pale, they have marched forward undismayed, in one firm unbroken phalanx, to victory and freedom." ${ }^{\text {41 }}$ This passage compares the Greek struggle to their ancient ancestors, using the historical imagery of the ancient Greek phalanx, Dwight not only invoked images of the past, but also paralleled the actions of the ancient Greeks with the Liberalism and revolutionary spirit of America and Greece. Dwight compared the Modern Greek people to the historical hero of Leonidas. This hero also having faced overwhelming odds from a Near-Eastern enemy, was depicted as a symbol of Greek freedom, and Dwight readily drew this parallel in his speech

This sort of casual reference requires a working knowledge of ancient history and, to an extent, an understanding of the "Myth of the 300." Paul Cartledge, a historian of Ancient Greek history, explains how the Battle of Thermopylae has been used (and still is used) as an important element in literature and history. The facts of the event are distorted and given elaboration for dramatic effect, but the "myth" of the event upholds Ancient Greek values of combat and virtue. Specifically, not an inch of ground was lost to the enemy and that the most honorable death was the one where the soldier lays down his

\footnotetext{
${ }^{41}$ Sereno Edwards Dwight, The Greek Revolution: An Address, delivered in Park Street Church, Boston. (Boston, MA: Crocker and Brewster, 1824), 16.
} 
own life defending the state even against the most hopeless of odds. ${ }^{42}$ This concept of defending freedom to the end is not unusual, however, our understanding of defending freedom has changed since the early $19^{\text {th }}$ century. While the modern person looks to contemporary examples and instances from American history, Americans of the early $19^{\text {th }}$ century looked to the Classics for examples of fighting for freedom. What makes Dwight's reference so telling, is not the fact he was using this specific reference, but that this speech was being delivered to a crowd of everyday Bostonians in two churches on two different occasions. This suggests that the people of Boston were familiar with ancient history and ancient authors, and that there was even a somewhat intellectual understanding of literature and ancient cultural concepts. This sort of casual reference in a church speech points to an American culture that had been influence by ancient works in all areas of society.

This single passage was not an anomaly; Dwight spoke several times about the Ancient World and further demonstrates the expectation that the audience had some familiarity with the Ancient World. In one particular passage, Dwight elaborated on how the Greek countryside was "Classic ground," and how it was the birthplace of freedom. ${ }^{43}$ By referring to Greek art, philosophy, and plays, Dwight attempted to illustrate how Greece was the cradle of Western culture and that it should be protected. Drawing upon the history of countryside and depicting the art of Phidias and Praxiteles, he argued that it took Western civilization 2000 years to reclaim such artistic perfection, and that if Greece

\footnotetext{
${ }^{42}$ Paul Cartledge, “Ancient Sparta in Modern Fiction,” History Today 65, no. 8 (August 2015), accessed October 16, 2016, http://www.historytoday.com/paul-cartledge/ancient-spartamodern-fiction

${ }^{43}$ Sereno Edwards Dwight, The Greek Revolution: An Address, delivered in Park Street Church, Boston. (Boston, MA: Crocker and Brewster, 1824), 7.
} 
could achieve freedom, then artistic expression could once again flourish. ${ }^{44}$ These illusions not only suggest a working knowledge of Greek history, but also speak to a comprehension of Classical art and the various artists throughout the Ancient World. The true extent of Classical knowledge that the average Boston layman had is up for debate, but what is absolutely certain, as demonstrated by Dwight's speech, is that there was at least a common culture formed around the Classics in America and even the poorest citizens had some knowledge of the Ancient World. Furthermore, Dwight's close association of antiquity with freedom and liberty demonstrates that the average citizen must have viewed American values and classical liberalism as being related to classical republicanism and the values of Ancient Greece and Rome.

It seems clear that Classical knowledge was not only a means of economic advancement for the common person, but also it was the cultural norm that had manifested itself during the American Revolution. ${ }^{45}$ One way we can see the common man utilizing ancient references and labels into their everyday life was through the lenses of slavery. In the $18^{\text {th }}$ century, middle-class and poor slave owners frequently named their slaves after historical figures from Greece and Rome. Run-a-way slave advertisements provide a glimpse into this era and demonstrate that the connection to Classical culture continued up until the close of the $18^{\text {th }}$ century. In one case, a run-away slave in 1782 was named Caesar. ${ }^{46}$ In 1799 , another run-away slave went by the same name. ${ }^{47}$ When slavery was abolished in the North by 1800 , run-away slave articles ended in northern publications. While the inhuman practice was finally abolished in the North, it

\footnotetext{
${ }^{44}$ Ibid.

${ }^{45}$ Carl J. Richard, The Founders and the Classics: Greece, Rome, and the American Enlightenment (Cambridge, MA: Harvard University Press, 1994), 20.

${ }^{46}$ Richard Jenkins, "Run Away," New York Gazette, April 22, 1782.

${ }^{47}$ Willett Carpenter, "Ran Away," Newport Mercury, September 24, 1799
} 
demonstrated that Classicism in America continued (at least in the North) up to the close of the $18^{\text {th }}$ Century.

In order to understand the extent to which slave owners named their slaves with ancient names, one must look further into the actual records that feature the known names of thousands of slaves. The Virginia Historical Society's Unknown No Longer database contains the names of over 1,500 slaves and encompasses documents that range from the mid- $18^{\text {th }}$ century up until the American Civil War. ${ }^{48}$ Using twenty-four Ancient Greek and Roman names, I searched the database and did a random sampling of how many slaves in Virginia's Ante Bellum South were recorded to have had a Classically inspired name. ${ }^{49}$ Approximately ninety-eight slaves were found in the database that contained one of the twenty-four names used, the most popular male names were Cato and Pompey, each with five hits, and the most popular name for the women (and overall) was Phyllis with twenty-five hits. Two of the slaves found in the database were actually owned by two of the Founding Fathers, Thomas Jefferson and George Washington. ${ }^{50}$ The names of the slaves were Julius and Minerva; it seems that Minerva was the illegitimate daughter of Thomas Jefferson. The sample collected proves that, at least, one out of every fifteen slaves in the Commonwealth of Virginia during the Ante Bellum period (roughly $7 \%$ of the population) had a name that was of either Greek or Roman origin.

${ }^{48}$ Nelson Lankford, “About this Project," Unknown No Longer: Virginia Historical Society, accessed March 1, 2017, http://unknownnolonger.vahistorical.org/about-this-project

${ }^{49}$ Names used were Antony, Cato, Caesar, Pompey, Julius, Marcus, Magnus, Plato, Scipio, Primus, Theophilus, Thaddius, Phillis/Phyllis, Venus, Lucinda, Minerva, Phoebe, Hector, Cupid, Daphne, Nero, Paris, Achillies, and Titus.

${ }^{50}$ Alex Garrett, Deed, 1813, of Thomas Jefferson, "Monticello," Albemarle County, Va., to his grandson Thomas Jefferson Randolph, "Monticello," Albemarle County, Va., for AfricanAmerican slaves (March 26, 1813), http://unknownnolonger.vahistorical.org/record/824/89\# ; George Washington and John Parke Custis, Inventory, ca. 1759, of African American slaves belonging to George Washington, and John Parke Custis through the estate of Daniel Parke Custis (1759), http://unknownnolonger.vahistorical.org/record/12114/697 
According to Peter Kolchin, Classical names were common during the late $18^{\text {th }}$ century and early $19^{\text {th }}$ century, composing of $21 \%$ of the population in the Carolinas in 1750 , and $14 \%$ of the population in the same states in $1809 .{ }^{51}$ While the use of Classical names decreased over time, it still remained prevalent during America's age of NeoClassicism and seemed to only decrease as the traditional education in the Classics slowly became less prevalent by the mid $-19^{\text {th }}$ century. The South continued slavery until the end of the Civil War and also proved to be one of the most Classically oriented populations in the United States as southerners used the ancient texts to justify slavery as well as adopt the ideas of Classical Pastoralism.

Southerners specifically relied upon Aristotle to justify their view and argued that the Aristotelian belief of "some were born to follow, while others were naturally meant to lead" supported the institution of slavery. ${ }^{52}$ Classical Pastoralism also pushed forth the idea of an agrarian nation and Southern plantation owners jumped upon this concept for defining themselves and justifying their occupation. Northerners, however, were not unaffected by the ideas of Classical Pastoralism; they too were heavily dependent on agriculture during the early years of the Republic and latched onto the same ideas, but not to the same degree as their Southern counterparts. Classical Pastoralism, as expressed by Virgil, emulated the idea that virtue and republican values came from one's mastery over one's farm and that the backbone of a society came from its farms. ${ }^{53}$ Americans adopted the same mentality and added late $18^{\text {th }}$ century economic theory and political ideology. Laissez-faire economics and free market capitalism were the preferred economic systems

${ }^{51}$ Peter Kolchin, American Slavery: 1619-1877 (New York, NY: Hill and Wang, 2003), $45-$ 46.

${ }^{52}$ Carl J. Richard, The Golden Age of the Classics in America (Cambridge, MA: Harvard University Press, 2009), 187-193.

${ }^{53}$ Ibid., 85. 
of the country, in fact, to many of the Founders and economic theorists, this form of economy protected the agricultural lifestyle of America. ${ }^{54}$ Jefferson's acquisition of territory under the Louisiana Purchase, although he himself viewed it as unconstitutional, allowed for the expansion of the agricultural society. Consistent with Jefferson's belief in Classical Pastoralism, the acquisition of this territory gave longevity to Republican virtues. ${ }^{55}$ Therefore, the more land and individual economic opportunity there was in the young Republic, the stronger American virtues and the Free Market system would become to defend these values.

Classical Pastoralism was so ingrained into Jefferson's mind that on occasion he chose to go against the founding principles of the nation as laid out in the United States Constitution. Instead he upheld an archaic ideology, which was based more in belief than fact, so as to create what he envisioned as an ancient agrarian utopia. Therefore, it is shocking to see that, only twenty years after the Louisiana Purchase, prominent and Classically minded leaders would betray both ancient and American principles to serve the financial needs of a handful of individuals. This, of course, refers to the way in which politicians were influenced by greedy merchants to forgo involvement in the Greek War for Independence.

It can be argued that, perhaps, America during the 1820s had moved away from ancient pastoralism and had begun to embrace industrialism and Manifest Destiny. Evidence, however, suggests that Pastoralism was still very much a part of American culture in the Northern states. Dwight, in his 1824 speech, lauds the Greek countryside and describes its agricultural lands with admiration. He views the geography of the

\footnotetext{
${ }^{54}$ Ibid., 86-87.

${ }^{55}$ Ibid.
} 
country as almost paradise-like. Looking to its strategic advantages and its historic neighbors, Dwight stated that it was obvious that Greece was the birthplace of democracy and the home of historic people and events. ${ }^{56}$ It is clear that the words of Virgil and Horace still resonated in the minds of everyday Americans, and that it was rich and prosperous farm land that made the ideal society. If America could so easily relate to and admire the Greek people on their history and agriculture alone, then why did America refuse to aid its revolutionary brother?

During the Ante Bellum period, Americans viewed themselves in a variety of ways, and most of these identities could easily be likened to the Greeks and their Revolution. If the uneducated American could not find commonality with the Greeks through the Ancients, he/she could look to the ideals of the American Revolution for this shared heritage. According to Edward Earle, at the beginning of the Greek War for Independence the Messenian Senate at Calamata made a direct appeal to the people of the United States using the pursuit of liberty, freedom, and virtue as relatable ideals that founded not only the American Revolution, but also the growing Greek Revolution. The appeal did not fall upon deaf ears. Not only did it reach the masses, but also it made its way to Edward Everett and John Quincy Adams. ${ }^{57}$ The public response burst from the heart of the American Revolution, the people were flattered and excited at how the Greeks turned to the United States as a model of "civil and religious liberty." Everett viewed the Greeks as fellow "patriots," and President Monroe encouraged the country in

${ }^{56}$ Sereno Edwards Dwight, The Greek Revolution: An Address, delivered in Park Street Church, Boston. (Boston, MA: Crocker and Brewster, 1824), 5-7.

${ }^{57}$ Edward Meade Earle, “American Interest in the Greek Cause, 1821-1827," The American Historical Review 33, no. 1 (1927): 45-46. 
its quest for liberty and independence. ${ }^{58}$ Thus, the Greek cause proved to be the catalyst of the American spirit, people echoed the philosophy of the American Revolution, lauded the virtues of democracy, and the love of liberty was all but dominant on the streets of the country. While the Classics appealed to the mind, culture, and heritage of the United States, it was Classical Liberalism that pulled at the heart and passion of the young nation.

Dwight, in his 1824 address, spoke to the common people of Boston and argued that the Greek people were expert capitalists and, despite the violation of their unalienable rights, they were still able to overcome the Turkish mercantile oppression and fight for their liberty:

In Greece, it [Greek economic liberty] has flourished in spite of opposition and rapacity. Those who engage in it are pillaged by the Turkish governors, are defrauded with impunity by the Turkish Merchants, and exposed by their very success to the loss of liberty, property and life. Yet thus pillaged, thus defrauded, they have extended it, with unbending resolution and increasing activity, until it covers all the shores and harbours... while their seamen are celebrated throughout the Mediterranean for the dexterity with which they manage their ships. It is owing to these causes, that... they have been the common carriers of the surrounding world, and have engrossed in their own hands almost all its local commerce." 59

Harkening to foundational ideas of the Social Contract and Unalienable Rights, as formulated by Rousseau, Locke, and Hobbes, which were important in the American Revolution, Dwight maintained that the Greek people's rights were being violated and they were yearning to rewrite the Social Contract. Furthermore, he pointed to economic oppression and likened the Turkish oppression to the mercantile system America freed itself from, and, like the late Colonial economy, credited the Greek people with a natural

\footnotetext{
${ }^{58}$ Ibid., 46.

${ }^{59}$ Sereno Edwards Dwight, The Greek Revolution: An Address, delivered in Park Street
} Church, Boston. (Boston, MA: Crocker and Brewster, 1824), 12. 
skill and desire for a Free Market economy. To Dwight and the people of Boston, the people of Greece faced the same exact challenge and were almost "indistinguishable" from those Revolutionary Bostonians.

To further this parallel, Dwight stated that the people of Greece have long yearned for liberty and, for centuries, have been oppressed by the Turks. Despite this desire, the Greeks faced an oppressor that was not 3000 miles away, like the British, but rather one that is right next-door. This direct subjugation, as a result, had always swiftly prevented any Greek rebellion from escalating to revolution. It was because of this that the Greek quest for liberty was so dire and it had almost been physically impossible to shake off the Turkish yoke of tyranny. ${ }^{60}$ Thus, Dwight argued that the Greeks cannot achieve their independence on their own and that help from their ideological brethren was key. Dwight even went as far to plant slogans into his speech that echoed the battle cries of the Revolution, in this case "We will be free; or we will perish," instead of "give me liberty or give me death. ${ }^{, 61}$

As previously discussed, Jefferson also viewed the Greek struggle in both the light of Classics and as a revolution similar to the American cause. In Jefferson's 1823 letter, not only did Jefferson prescribe the need for a liberal Greek constitution based upon one of the United States' states, but also recommended that the Greeks uphold the Social Contract and ensure that the freedoms of speech, assembly, the press, religion, and a trial by jury be protected. ${ }^{62}$ Therefore, not only was this patriotism felt by the common man, but also even the Founding Fathers felt a philosophical kinship with the Greek people.

\footnotetext{
${ }^{60}$ Ibid., 14-15.

${ }^{61}$ Ibid., 16.

${ }^{62}$ Thomas Jefferson to Adamantios Coray, 31 October 1823, in America in Greece: A traditional Policy, ed. David M. Robinson (New York, NY: Anatolia Press, 1948), 42.
} 
This shared patriotism was even echoed in the rotunda of the Capital Building when Daniel Webster argued that America has played a part in the revolutions in Europe and that now the Greek people are clamoring for liberty. Furthermore, Webster said that America should not only encourage such movements but also "go to prostate the liberties of the entire civilized world, whether existing under an absolute, a monarchal, or a republican form of government. They are doctrines which have been conceived with sagacity, they are pursued with unbroken perseverance, and they bring to support, a million and a half of bayonets. ${ }^{, 63}$ Thus, Webster argued that it was almost a civilized duty on the part of the United States to spread liberty through encouraging and participating in revolutionary movements in other nations, in this case Greece.

Endless examples of state resolutions, local speeches, and organizations dedicated to supporting the Greeks all professed support for the liberty of other nations. These organized proclamations throughout the country not only justified their support through the ideals of the American Revolution, but also viewed the Greeks as fellow patriots fighting the same fight America did several years ago. What is certain is that every political organization, prominent individual, and (to an extent) every citizen found cause through their similarities with the Greeks in Classical influence and ideals of the Revolution. Alongside the rhetoric of Revolution and the Classical world, many of the accounts also distinguish the cause as a Christian duty. Specifically, they viewed the need to support the Greeks as both a religious obligation and as an act of charity because of the common belief in a similar religion. Again, all levels of society seemed to share this view and, in some cases, seemed entirely interwoven with Revolutionary ideas and/or Classical

\footnotetext{
${ }^{63}$ Daniel Webster, Mr. Webster's Speech (January 1824), in America in Greece: A traditional Policy, ed. David M. Robinson (New York, NY: Anatolia Press, 1948), 77-78.
} 
thought. Repousis argues that several Americans viewed the conflict as both a

humanitarian cause and as a holy war because the Greeks were fellow Christians. ${ }^{64}$ Earle further postulates that the war was viewed as a fight against the spread of Islam, as well as a struggle for religious liberty for fellow Christians. ${ }^{65}$

This sort of religious and Christian liberation is downplayed by both Repousis and Earle. In fact, the feelings of religious brotherhood and crusading were almost fanatical and imperialistic in nature. Americans did not just view aiding this cause as a duty, but rather viewed it as a holy obligation. Jonathan P. Miller, a military volunteer from the United States that fought alongside the Greeks, wrote, "If there was ever a country, that called for the charities of the Christian world, that country is Greece." ${ }^{, 66}$ In this respect, Miller saw the Greek War for Independence as a type of Christian charity; it was a sacred "good deed" to help another Christian nation. Furthermore, this passage implies that Christian nations should feel morally obligated to help the Greeks out of both charity and common Christianity. George Jarvis, another volunteer on the Greek front, also viewed the Greeks as Christian brothers and saw the cause as a noble one. What is most interesting about Jarvis' view, in contrast with Miller, is the lumping of liberty, Classicism, and Christianity all together when explaining the nobility in fighting for the Greek cause. ${ }^{67}$ Jarvis described his Greek brothers-in-arms as "patriotic and brave" and described their efforts in the war as "principled achievements." In this context, Jarvis was

\footnotetext{
${ }^{64}$ Angelo Repousis, "'The Cause of the Greeks:' Philadelphia and the Greek War for Independence, 1821-1828," The Pennsylvania Magazine of History and Biography 123, no. 4 (October 1999): 333-335.

${ }^{65}$ Edward Meade Earle, "American Interest in the Greek Cause, 1821-1827," The American Historical Review 33, no. 1 (1927): 44-45.

${ }^{66}$ Jonathan P. Miller to the Greek Committee of Boston, 14 January 1825, in Letters From Greece, ed. Brown University (Providence, RI: Brown University, 1825), 9.

${ }^{67}$ George Jarvis to the Greek Committee of Boston, 6-18 January 1825, in Letters From Greece, ed. Brown University (Providence, RI: Brown University, 1825), 12-13.
} 
describing their revolutionary spirit and noticed the makings of liberty in the Greek people. Directly after this statement, Jarvis also described his efforts in the war and specifically cited helping fellow "Christian fugitives" captured by the Turks. Most interestingly, Jarvis mentions how the Greeks reminded him of their forefathers, in this context we can only assume that Jarvis was referring to Ancient Greece. ${ }^{68}$

This referencing to the Classics, Christianity, and the American Revolution reveals some important clues to how many Americans viewed the world and the Greek cause. First, the Americans engaged in the issue of Greek Independence had an expectation or picture of what the Greek people were and often attributed the actions of the Greeks to this idealized image that was formulated in the American imagination. Second, not only did Americans view the Greeks through the lenses of Christianity, Classicism, and Liberalism, but also these interpretations seemed to be one in the same and entirely interdependent.

To understand how intimately each one of these perspectives depended on each other, one must understand how the ideology Orientalized the Greeks when faced with something the Greeks did or believed that was in utter contrast to the American perception of them. For instance, Col. Jarvis discussed the strange religious practices of the Greeks and found their veneration of saints to be both foolish and "erroneous" in the practice of worshiping God. ${ }^{69}$ Ironically, Jarvis retracted the statement and argued that liberty and science were opening up their minds. Therefore, Jarvis makes the assertion that the virtues of the Enlightenment and Liberalism will "civilize them" and correct them in their religious practices. In context, the United States at this time was largely

\footnotetext{
${ }^{68}$ Ibid.

${ }^{69}$ Ibid., 18.
} 
Protestant and tended to assume Christians should conform to a certain set of beliefs. The Greeks, who practice Orthodox Christianity, have a completely different set of practices that most Americans were not familiar with. As is consistent with Edward Said's theory on Orientalism, Americans used their historical knowledge of Ancient Greece, their experience in forming a government based on Liberalism, and their own view of what qualifies as "proper Christianity" to impose certain assumptions about the people of Greece ${ }^{70}$ Essentially, this assumed authority placed itself as the standard of "civilization" and characterized other cultures based upon how similar or different they were from the imposing culture. In the case of Americans interpreting modern day Greeks, they saw "potential for civilization" and therefore identified with the Greeks while aiming to “correct" certain characteristics of their culture. Jarvis, Miller, and, most especially, Dwight all impose their own views on the Greeks and the potential of a successful independence movement.

Jarvis was convinced that the American system was the correct and "civilized" way of life, he explained that there was much potential in the people of Greece and they could soon join the civilized nations of the world. Jarvis argued that, through the ideological guidance of Americans and the work of Protestant missionaries, the Greek people would adopt American and proper Christian customs. ${ }^{71}$ Furthermore, if the Greeks assimilate to the "civilized" lifestyle and beliefs of America, then Christianity could spread throughout the world. This sort of assumption and ideological narrowness not only demonstrates how Americans viewed Western ideas as being "superior" and civilizing at

\footnotetext{
${ }^{70}$ Edward W. Said, "Knowing the Oriental," in Readings for a History of Anthropological Theory, ed. Paul A. Erikson and Liam D. Murphy (Toronto, ON: University of Toronto Press, 2017), location 13560-13569, Kindle edition.

${ }^{71}$ George Jarvis to the Greek Committee of Boston, 6-18 January 1825, in Letters From Greece, ed. Brown University (Providence, RI: Brown University, 1825), 20.
} 
this time, but also demonstrate that many Americans viewed Christianity, Classics, and Liberalism as interdependent ideologies that helped spawn the other. In Jarvis' mind and the minds of many other Americans during this time, Liberalism, the Classics, and Christianity were a civilizing force. While his Greek contemporaries practiced a different form of Christianity, he believed Liberalism and the Classics would encourage them to become "civilized."

Dwight further mixed these three areas by placing Christianity into an Ancient context and demonstrated the most Orientalized perspective of the different accounts. At one point Dwight attributed the entire intellectual and artistic progress of Europe to the works and creativity of the Ancient Greeks. Pointing to Euclid, Aristotle, Solon, Lycurgus, Homer, Pindar, Leonidas, and many others, Dwight argued that the science of law, cultural values, government, philosophy, and literature all have their beginnings in Greece. ${ }^{72}$ In the same address, however, Dwight linked Greek culture to modern Christianity. Specifically, he referenced how Koine Greek was the original language of the New Testament, how Constantine declared the Roman Empire Christian from the Eastern capital city of Constantinople, and how the Greek people have always been the gateway to Christendom and have always fought off Islamic invaders. ${ }^{73}$ Furthermore, Dwight envisioned an expanding Christian nation and used Ancient geographic landmarks, such as the Danube River, Asia Minor, and Damascus to mix both religion and the ancient world into one vision. ${ }^{74}$

\footnotetext{
${ }^{72}$ Sereno Edwards Dwight, The Greek Revolution: An Address, delivered in Park Street Church, Boston. (Boston, MA: Crocker and Brewster, 1824), 8-9.

${ }^{73}$ Sereno Edwards Dwight, The Greek Revolution: An Address, delivered in Park Street Church, Boston. (Boston, MA: Crocker and Brewster, 1824), 10.

${ }^{74}$ Ibid., 25-26.
} 
Dwight further described Christianity and Liberalism as a "uniting" force that will start from Greece. In fact, he looks to the Serbians, Moldavians, and other Eastern Europeans and sees them as people "ripe for revolt" and professing the "Greek Religion." Dwight implies that these people had lacked direction with their efforts and would be quick to violence. Dwight believed that only Greece, the genesis of civilization, could give the nations of Eastern Europe direction toward progress. It is through a common faith and embrace of liberty that the Greeks could bring Eastern Europeans into the fold of modern Christendom. ${ }^{75}$

Dwight did not stop at Europe. By combining Liberalism and the spreading of Christendom, he envisions how Greece "will rise up and send forth her own evangelists to visit other climes. ${ }^{, 76}$ Essentially, Dwight described a crusade based in Christianity and Liberalism that would start from Greece and spread throughout the Middle East and Southeastern Europe. Dwight believed revolution after revolution would spread from Turkey to Palestine to Egypt and to the Mesopotamian River. Not only would each of the people in these countries adopt Liberalism and Liberty, but also they would drop "Mohammudism" in exchange for Christianity. In this "liberating" process various sects of Christianity will rise up and rejoin "Modern Christendom," such as Coptic Armenians and Syrians. ${ }^{77}$ Needless to say, Dwight had a narrow view of the world and, to a degree, was an ideologue. So strongly did he believe that Christianity, Liberalism, and Classicism were interdependent and a civilizing force that he "knew" Christianity would spread across the Middle East if the Greek Revolution was successful. To Dwight, if a nation had all three qualities, it would be impossible for its neighbors to resist joining

\footnotetext{
${ }^{75}$ Ibid.

${ }^{76}$ Ibid., 27.

${ }^{77}$ Ibid., 26-28.
} 
Christendom through revolution. Dwight's perspective follows Said's description of Orientalism and how there is a self-justification on the interfering culture's part to "deliver civilization" to the "lesser culture" and, with their guidance, they would guide the rest of the region toward civilization. ${ }^{78}$ In Dwight's world-view, the introduction of Liberalism, Protestantism, and Classicism by Americans into the country of Greece will cause a "domino effect" and, because the combination of all three aspects of American society are so "civilizing," a massive wave of revolutions would sweep across the Middle East and South Eastern Europe.

What is most revealing about this passage is not the content, per se, but rather the intended audience of this speech. The fact that Dwight referred to both Classical and Christian ideas in the same breath demonstrates an assumed co-dependence; both feed off each other and are jointly civilizing forces. The audience, the common people of Boston, both knew and accepted this. In their minds, it seems that all three of these ideas went hand in hand, and that a Liberal Crusade across the Middle East seemed both highly appealing and logical. Significantly, this demonstrates that, a large portion of American society, to an extent, identified with the ideas of the Revolution, Liberalism, and Classicism. They not only understood the basics of most ideas, but also they viewed each of these concepts as one in the same, each inspiring the other. To Ante Bellum America, civilization and the ideals of American society were built upon the literature and history of the Ancients, one's faith in Christ, and the spirit of the Revolution. Thus, it was not only one of the interests of the American public to be involved, but also it was a cultural obligation that touched the very core of the American identity.

\footnotetext{
${ }^{78}$ Edward W. Said, "Knowing the Oriental," in Readings for a History of Anthropological Theory, ed. Paul A. Erikson and Liam D. Murphy (Toronto, ON: University of Toronto Press, 2017), location 13584-13594, Kindle edition.
} 


\section{Part II: Sacrifices for the Cause and the Issue with the Monroe Doctrine}

American interest in the Greek War for Independence went beyond a simple political infatuation. American sympathy was so strong that, even when formal diplomatic action failed at the federal level, individuals and organizations invested themselves into the Greek cause. Veterans and active soldiers volunteered to fight alongside their Greek brethren, and influential public figures and intellectuals founded and led organizations that brought aid to Greece. Those that lacked the financial, political, or personal capacity to volunteer contributed what they could from their own funds and resources to aid in the cause. Local and state governments made impassioned resolutions that urged Congress to get involved. These municipalities even passed bills to send local and state funds to assist in the Greek cause. On the federal level, the topic was hotly contested, and prominent politicians, specifically Henry Clay and Daniel Webster, made some of the most eloquent speeches and arguments that ever echoed in the Capital Rotunda.

Despite the strong advocacy of individuals, organizations, and state governments, the formal resolution to support the war died on the House floor. On the surface, diplomatic obligations and the Monroe Doctrine were blamed for the death of the bill, but, upon closer examination, it becomes evident that behind the scenes it was a different story. Webster, a staunch advocate for the conflict, suddenly backed down and allowed the resolution to fizzle. President Monroe was conflicted on the Greek War for Independence and held off on showing full support or neutrality for a long period of time. When the decision was make, conveniently, John Quincy Adams (an open opponent to 
the conflict) proved to be the one that finally convinced the President to forgo the conflict. Through the examination of the financial and personal relations of the politicians involved in making the final decision, it becomes evident that personal agendas, rather than the best interest of the nation or the Greeks, directed American foreign policy.

While the fate of a nation was decided in the backrooms of the legislature, everyday American men and women willingly sacrificed their time and money for the Greek cause. For instance, Dr. Samuel G. Howe, a prominent Boston physician, volunteered to serve in the Greek army and helped care for the wounded on the battlefield. His assistance proved to be a crucial factor in maintaining the Greek cause, as he served as both a medic and as an officer. Eventually, he became the surgeon general for the Greek Navy, and became an active supporter of the Greeks after returning to Boston. There, he both raised money and directed resources for the Greek relief effort. ${ }^{79}$ Howe was not the only American to serve alongside the Greeks—-George Wilson of Providence, Rhode Island and James Williams of Baltimore, Maryland served with honor in the Greek navy. Wilson was noted as a sharp gunner, and Williams served with a “calm and heroic spirit," despite suffering broken limbs in combat. ${ }^{80}$ American volunteers not only supplied extra manpower and medical assistance, but they also served as battle-hardened commanders. In particular, Jonathan Miller, a veteran of the War of 1812, provided both leadership and experience on the frontlines. ${ }^{81}$ Miller also served as

\footnotetext{
${ }^{79}$ Edward Meade Earle, "American Interest in the Greek Cause, 1821-1827," The American Historical Review 33, no. 1 (1927): 54-55.

${ }^{80}$ Ibid., 55-56.

${ }^{81}$ Ibid., 55.
} 
an agent for relief organizations and provided information to the Greek Committee in Boston. $^{82}$

While some Americans served directly with Greek forces, others acted on behalf of organizations such as Greek Independence Committees, churches, and even state and local government. Serving as informants and observers, these individuals let their fellow Americans know the progress of the war and what supplies were needed on the frontlines. Jonathan Miller was not the only American to do this-George Jarvis corresponded with the Greek Committee. He informed them of the conditions in Greece, and made recommendations on both appropriate supplies and effective interactions with Greek soldiers. ${ }^{83}$ Furthermore, Jarvis made recommendations to the Greek Committee about who should volunteer for the cause - qualified individuals, not just adventure-seeking fighters. Specifically, Jarvis recommended that volunteers be completely independent, accustomed to working in hard conditions, willing to learn the language and customs of the Greeks, "be of sound character, and be willing to take on the cause as almost a sacred pledge, and willingly suffer for it while forgoing private interests." ${ }^{, 84}$

Jarvis and Miller's near-constant line of communication with the Greek Committee in Boston demonstrates that this American organization was essentially "waging war" and attending to the responsibilities of the state. Their effort required an excellent flow of information in order to properly distribute resources to the frontlines. Miller, Howe, and Jarvis also required continual funding from the Greek Committee of Boston just to meet the essentials of food, clothing, and ammunition.

\footnotetext{
${ }^{82}$ Jonathan Miller to The Greek Committee of Boston, December 11, 1824, in Letters From Greece, ed. Brown University (Providence, RI: Brown University, 1825), 4-5.

${ }^{83}$ George Jarvis to the Greek Committee of Boston, 6-18 January 1825, in Letters From Greece, ed. Brown University (Providence, RI: Brown University, 1825), 11-16.

${ }^{84}$ Ibid., 17.
} 
Greek Committee members relied upon donations and fundraising to meet these needs, Edward Everett, a leading member of the committee, routinely reached out to wealthy individuals for aid. In one letter to Col. Thomas H. Perkins, Everett asks that Perkins support Dr. Howe and explains that Everett has already given so much to the cause that he is unable to extend his resources. Offering reimbursement to Col. Perkins, Everett politely begs for his assistance in aiding this volunteer in Greece. ${ }^{85}$

Everett and others of the Greek Committee also contacted captains, commodores, and sailors to ask for their aid in delivering donations and resources to the volunteers in Greece. In a letter to Commodore Rodgers, Edward asks if the Commodore would look after cargo being sent to Greece, and see to it that the ship carrying the cargo fell under his command. Furthermore, Everett attempts to appeal to Rodgers' faith by pointing to the "fellow men and fellow Christians in Greece." ${ }^{86}$ As discussed in Part I, this sort of philosophical and cultural appeal is evidence of how meaningful the conflict was to the American mindset at the time. Furthermore, the Christian brotherhood, as well as the brutality of the conflict, made the Greek conflict a humanitarian cause. Not only was the Greek Revolution understood as a political cause, but also it was accepted as a moral obligation that appealed to all members of American society. This letter proves that not only did this committee and several others, including New York and Philadelphia, raise the funds to fight the conflict as though they were at war, but they also attempted to facilitate the transportation and safe passage of goods to their "soldiers" in Greece.

\footnotetext{
${ }^{85}$ Edward Everett to Col. Thomas H. Perkins, 27 December 1826, box 2 folder 7, Thomas Handasyd Perkins Papers, Massachusetts Historical Society, Boston, MA.

${ }^{86}$ Edward Everett to Commodore John Rodgers, 3 March 1827, in America in Greece: A traditional Policy, ed. David M. Robinson (New York, NY: Anatolia Press, 1948), 58.
} 
These Greek Committees even appealed to national politicians for financial support. In one case, the Greek Committee of Boston sent a letter to President John Quincy Adams asking for the government to send money to Captain Jonathan Miller, fighting in Greece. ${ }^{87}$ What makes this appeal unique was its personal connection between the President and a member of the Committee, specifically Edward Everett. Both politicians were Boston born and bred, and both participated in the same political circles, specifically the Federalist Party, and what would eventually become the Whig Party. During the 1828 election, Everett served as an advocate for Adams and worked with Daniel Webster to push forward a strong campaign for the incumbent president. ${ }^{88}$ Everett was also a U.S. Congressman for the Commonwealth of Massachusetts in 1824 and he was active in Bostonian society leading up to his election. It is be highly unlikely that John Quincy Adams would not have been acquainted with Everett prior to his election to office.

An example that gives us a glimpse into the closeness of the relationship between these two men is during John Quincy Adams' funeral in 1848. Everett, then not elected to any office, delivered the eulogy on John Quincy Adams and his character at the former President's funeral, demonstrating both a professional and personal relationship between both politicians. ${ }^{89}$ Despite John Quincy Adams' opposition to the war, Everett was able to call upon a personal and political relationship to ask for aid to the conflict. The

\footnotetext{
${ }^{87}$ The Greek Committee of Boston to the President of the United States, 29 September 1825, in America in Greece: A traditional Policy, ed. David M. Robinson (New York, NY: Anatolia Press, 1948), 54.

${ }^{88}$ Carl Seaburg and Stanley Paterson, The Merchant Prince of Boston: Col. T.H. Perkins, 1764-1854 (Cambridge, MA: Harvard University Press, 1971), 350-351.

${ }^{89}$ Edward Everett, "The Character of Quincy Adams," Orations and Speeches, Bartlby.com, 1848, http://www.bartleby.com/400/prose/949.html
} 
members of these committees, similarly, called upon their personal and political connections to ask for support.

While these efforts had success in bringing aid to the Greeks, the cost on of the Greek committees, individuals, and other politically motivated organizations had little to no pay-back and, more often than not, individuals ended up putting themselves into positions that could ruin their lives. American volunteers put their lives on the line and, these that survived the war, had sacrificed years of their lives to a cause on the other side of the world. Although the people who gathered funds and distributed resources had great success, their efforts often experienced financial difficulties and constantly struggled to maintain the flow of funds. Even Everett, a moderately well-to-do politician, community organizer, and Classical scholar, found that he had overextended himself in support of the cause..$^{90}$ Therefore, it is evident that such direct aid to the Greek cause was a personal act for many Americans, which demonstrates a sense of common identity with the Greek people. Whether it was out of a common Christian belief, ideas of the American Revolution, or a sense of indebtedness to the Ancient Greeks, Americans were deeply committed to the conflict.

Boston was not the only city to organize a Greek Committee. The Committee of the Greek Fund of the City of New York also supported the conflict. Much like the statements given by Dwight and Everett on the conflict (both were members of the Boston Committee), this Greek committee in New York saw the war as a Christian duty, something in line with the ideas of the American Revolution, and an obligation to repay

\footnotetext{
${ }^{90}$ Edward Everett to Col. Thomas H. Perkins, 27 December 1826, box 2 folder 7, Thomas Handasyd Perkins Papers, Massachusetts Historical Society, Boston, MA.
} 
the Ancients. ${ }^{91}$ Philadelphia also formed its own committee to support the conflict, and was followed by other cities across the United States. Both private citizens and local organizations across the country published articles in newspapers that championed the cause and plead for further assistance for the Greek people. ${ }^{92}$ This widespread show of support demonstrates an organic effort on the part of the general public, further establishing the importance and political significance of the conflict to everyday Americans.

These efforts did not just stay with private individuals and socio-political community organization - they also extended to the operations of local and state governments. Citizens of New York, Boston, and other cities signed petitions that urged United States Congress to aid the Greek Revolution and to at least recognize the independent sovereignty of the Greek people. Furthermore, these petitions used the ideas of the American Revolution to justify their position, and they made mention of the movements for independence in South America. They cited that Greece and all of these other revolutionary movements should be considered as one and the same, as well as “equally deserving” of the United States' support. ${ }^{93}$

At the national level, President James Monroe first recognized the cause of the Greek people in 1822, and expressed deep philosophical sympathy on the behalf of the people of the United States. Citing both the Ancient World and a shared interest in liberalism, Monroe made it clear that the United States hoped that the Greek Revolution

${ }^{91}$ The Committee of the Greek Fund of the City of New York, "Address of The Committee of the Greek Fund of the City of New York," in America in Greece: A traditional Policy, ed. David M. Robinson (New York, NY: Anatolia Press, 1948), 136-142.

${ }^{92}$ David M. Robinson, America in Greece: A traditional Policy, ed. David M. Robinson (New York, NY: Anatolia Press, 1948), 158-166.

${ }^{93}$ Ibid., 131-135. 
would succeed. ${ }^{94}$ Local and state governments applauded this sympathy from the President and, through the passage of state resolutions, expressed their own sympathy for the conflict, and even urged immediate recognition of Greek Independence. ${ }^{95}$ South Carolina, Maryland, Kentucky, New York, and several other state legislatures passed legislation and resolutions that expressed the same sympathies, each drawing upon the Ancient World, Classical Liberalism, and Christianity.

Some of the strongest advocates for the Greek cause came from city and county governments. Poughkeepsie, New York not only demanded that the Greeks receive their independence, but also noted common Christian heritage with the Greek people. Also in their statement, the people of Poughkeepsie mentioned the assistance of Congressman Daniel Webster and how, along with his support, they wanted to extend support to the Greek cause. Thus, town and local governments were working with national figures to raise awareness of the issue. Moreover, the government of Poughkeepsie ordered and appointed a legitimate governmental committee to collect and send aid to the people in Greece. ${ }^{96}$ It is clear that even state and local governments were taking legal action to assist the Greek cause and committing their own community resources to a foreign cause. This movement was not just cultural and the cause of philanthropic organizations, but rather a legitimate political issue that was serious enough to yield legislation at the local level.

${ }^{94}$ James Monroe, "Extracts From James Monroe's Annual Message to Congress," in America in Greece: A traditional Policy, ed. David M. Robinson (New York, NY: Anatolia Press, 1948), 67.

${ }^{95}$ David M. Robinson, America in Greece: A traditional Policy, ed. David M. Robinson (New York, NY: Anatolia Press, 1948), 68-73.

${ }^{96}$ Citizens of Poughkeepsie, "Resolution Passed by Citizens of Poughkeepsie," in America in Greece: A traditional Policy, ed. David M. Robinson (New York, NY: Anatolia Press, 1948), 127-128. 
The Greek cause inspired political and social organization, for individuals were acting both separately and cooperatively to achieve goals. Whether by urging the government to take action or acting independently to cause this change, average citizens decided to become involved. Churches across the country were taking up collection for the Greek cause and dedicating crosses to the people in Greece. College students at Yale, Columbia, Brown, and several other major institutions ran fundraisers for the Greek people. ${ }^{97}$ The numerous Greek Committees across the country, which were started or inspired by Everett, Webster, and others, distributed pamphlets, threw countless balls and fundraising parties, and hosted auctions for the cause. ${ }^{98}$ Private individuals also sent aid through the Greek Committees; among them were students that donated their money, workers that reserved part of their paychecks for the Greeks, merchants that committed a percentage of their profits to Greece, and ship owners that designated cargo space on their vessels for resources that were to be sent to Greece. ${ }^{99}$ Nearly every segment of American society donated to the cause, and political debates and discussions on the issue were commonplace. There was not a major city in America that did not have some sort of Greek committee and program (whether it was event or donation system) committing resources to the Greek War for Independence. ${ }^{100}$

Thus, it is irrefutable that the American people from all segments of society were not only philosophically supportive of the Greek cause, but also financially committed to supporting the Greek people. The will of the people was clear-Greece was an ally, and the United States citizenry was willing to put their lives on the line for her people. In light

\footnotetext{
${ }^{97}$ Edward Meade Earle, "American Interest in the Greek Cause, 1821-1827," The American Historical Review 33, no. 1 (1927): 49-51.

${ }^{98}$ Ibid., 51-52.

${ }^{99}$ Ibid., 51.

${ }^{100}$ Ibid., 51-54.
} 
of this, it is a paradox that the United States kept out of this conflict and did not even formally recognize the independence of Greece until the War ended. Did not the government of the United States represent the will of the people? What happened and why did formal recognition fail? Most historians have attributed this failure to the Monroe Doctrine and John Quincy Adams' political ties.

Traditionally, historians have pointed to Monroe's mention of Greece, the remaining South American colonies, and the new Latin American Republics in his 1823 speech as the reason federal support of the Greek War of Independence failed. ${ }^{101}$ In Monroe's address, Greece is regarded with little actual commitment. Although the United States hoped and wished the Greeks would become independent, Monroe neither recognized an actual Greek sovereignty nor implied any action on the part of the United States. ${ }^{102}$ Monroe, rather, justified that Greece's effort has already made it impossible for the Turks to regain full control of the country. He added that there were no other nations opposing Greek independence and, in fact, most European powers had already endorsed the movement and offered support, thus it was not necessary for the United States to become involved. ${ }^{103}$ Immediately after this statement, Monroe made it clear that Europe should stay out of the Western Hemisphere and no longer pursue colonial expansion. Moreover, Monroe recognized the independent South American governments and viewed them as being "now and forever free." Nevertheless, in the same breath, the President also promised to not interfere into any current colonial possessions in the Western

\footnotetext{
${ }^{101}$ Angelo Repousis, "'The Cause of the Greeks:' Philadelphia and the Greek War for Independence, 1821-1828," The Pennsylvania Magazine of History and Biography 123, no. 4 (October 1999): 338-340.

${ }^{102}$ James Monroe, "Seventh Annual Message (Monroe Doctrine) (December 2, 1823)," Miller Center of the University of Virginia (Charlottesville, VA: University of Virginia website, 2016) http://millercenter.org/president/monroe/speeches/speech-3604

${ }^{103}$ Ibid.
} 
Hemisphere. ${ }^{104}$ When one considers how Monroe expected to treat European affairs, the President said:

Our policy in regard to Europe, which was adopted at an early stage of the wars which have so long agitated that quarter of the globe, nevertheless remains the same, which is, not to interfere in the internal concerns of any of its powers; to consider the government de facto as the legitimate government for us; to cultivate friendly relations with it, and to preserve those relations by a frank, firm, and manly policy, meeting in all instances the just claims of every power, submitting to injuries from none. ${ }^{105}$

Essentially, Monroe declared Europe as forever "off limits" and that the only concern of the United States should be the Western Hemisphere. Historians, especially Kaplan, have traditionally pointed to this passage in the Monroe Doctrine as the reason for staying out of the Greek War for Independence and have argued it as a matter of "diplomatic principle."106 In essence, if the United States were to get involved in Europe then it would give European powers license to interfere in the Western Hemisphere.

Furthermore, several historians have also argued that there was a political dimension to the situation and that John Quincy Adams stood much to lose by essentially ruining the "Era of Good Feelings." The Secretary of State and President, John Quincy Adams, was a former Federalist and still had many connections to the remaining Federalists in United States politics (i.e. his father and most of his peers in Boston). Kaplan has argued that if the United States had become involved in Greece that it would have ruined Adam's chance at the presidency in 1824 and later

\footnotetext{
${ }^{104}$ Ibid.

${ }^{105}$ Ibid.

${ }^{106}$ Michael E. Chapman, "Pragmatic, ad hoc Foreign-Policy Making of the Early Republic:
} Thomas H. Perkins's Boston-Smyrna-Canton Opium Model and Congressional Rejection of Aid for Greek Independence," International History Review 35, no. 3 (2013): 451-452. 
in $1828 .{ }^{107}$ Federalists at this time had earned a bad reputation from the War of 1812 with their secession attempt and subtle aid to the invading British. In the Greek War for Independence, the British were assisting the Greeks. In the eyes of Adams and many Americans, jumping into a foreign conflict on the side of an enemy you just finished a war with was, in Adams' view, political suicide and had a bitter taste of treason. ${ }^{108}$ Using his influence on Monroe and his position in the government, Adams steered the country away from the conflict and ensured his viability in the next election.

Historians have also argued that both economic and diplomatic concerns pushed the young nation to avoid the conflict. Since, John Quincy Adams (maybe out of his own political needs) discouraged any action, as he feared it would lead to a war with not only Turkey, but also the Barbary States. Facing a war with these two states would have brought economic hardship and would have prevented the United States from having any access to Mediterranean trade. ${ }^{109}$ This, of all these different interpretations of the reasoning for staying out of the conflict, provides the only definitive recorded evidence of John Quincy Adams expressing an actual reason for staying out of the conflict. Adams' reason, beyond any speculation, points to a direct economic concern that was both true and potentially damaging. This, however, brings into question a rather telling concern about Adams; truly the United States economy would have been cut off from the Mediterranean, but was it really such a

\footnotetext{
${ }^{107}$ Lawrence S. Kaplan, "The Monroe Doctrine and the Truman Doctrine: The Case of Greece," Journal of the Early Republic 13, no. 1 (Spring 1993): 3-4.

${ }^{108}$ Ibid.

${ }^{109}$ Angelo Repousis, “'The Cause of the Greeks:' Philadelphia and the Greek War for Independence, 1821-1828," The Pennsylvania Magazine of History and Biography 123, no. 4 (October 1999): 338
} 
concern? The United States would have been a part of an entire Naval coalition and trade, at least with Western European countries, could have continued. America was also conducting trade with the Caribbean, South America, and East Asia, would access to the Eastern Mediterranean really have devastated the United States economy? The words and actions of John Quincy Adams and other politicians raise some concerns and inconsistencies with the typical historical explanation of America's neutrality.

In December 1823 and January 1824, immediately following the declaration of the Monroe Doctrine, Congress began a spirited debate on handling the situation in Greece. The first step in becoming involved in Greece was recognizing Greek sovereignty and appointing a representative or commissioner to the newly formed Greek government, in January of 1824 Congress discussed this very issue. ${ }^{110}$ According to Chapman, and the speeches from a variety of prominent Congressmen at the time, there was passionate support for the Greek cause and key members of Congress were all lending support. ${ }^{111}$ Initially, it seemed that there was significant support in Congress and that, instead of tabling the issue as Monroe had suggested in his December 2, 1823 speech, Congress would pass legislation to support the resolution recognizing Greek sovereignty. Webster and Clay each delivered passionate speeches that earned great praise and gave the movement a real shot of passing. When it came time to vote, the resolution was formally tabled and, despite

${ }^{110}$ David M. Robinson, America in Greece: A traditional Policy, ed. David M. Robinson (New York, NY: Anatolia Press, 1948), 75.

${ }^{111}$ Michael E. Chapman, "Pragmatic, ad hoc Foreign-Policy Making of the Early Republic: Thomas H. Perkins's Boston-Smyrna-Canton Opium Model and Congressional Rejection of Aid for Greek Independence," International History Review 35, no. 3 (2013): 450-451. 
earlier passions, Webster and Clay quietly stepped aside and let the resolution die on the House Floor. ${ }^{112}$ Understandably, the resolution had been subtly discouraged by Monroe and, in the Era of Good Feelings, the President's position perhaps deeply resonated with members of Congress on both sides of the isle. Webster, however, did not give any more fight to the cause and, despite his passionate speech, Webster demonstrated only indifference when the bill was killed, what changed his mind between his speech and the final vote?

Monroe's dismissal of the bill also raises some questions, on one hand the President supported the Greek cause out of the interest of liberalism and thought it would not be a major issue if a commissioner was appointed. On the other hand, however, he more strongly discouraged the action because the Turks had "forever lost dominion" over the region and that there was already enough international support to ensure that the Greeks achieved independence, in his mind, it was not worth breaking American neutrality. ${ }^{113}$ Monroe believed that discussion of the issue was "important" and that it was symbolic to have a debate in Congress concerning the issue. ${ }^{114}$ This odd explanation does not seem to achieve any clear political objective other than raising awareness about the issue. But, if one is intending to only have a "discussion," then why provide the opportunity for it to possibly pass?

According to Repousis, Monroe was very divided on the issue of supporting Greece and even considered outright recognizing Greek Independence. Adams

${ }^{112}$ Ibid., 451-452.

${ }^{113} 18^{\text {th }}$ Congress of the United States, "Debates and Proceedings, 1789-1824," Annals of Congress, from A Century of Law Making for a New Nation, accessed November 26, 2016, http://memory.loc.gov/cgi-bin/ampage

${ }^{114}$ Ibid. 
intervened and swayed Monroe to not outright support their independence but rather stick to encouraging the independence of other nations while maintaining a non-interference policy. ${ }^{115}$ This half-committed policy of "supporting without supporting" is exceptionally odd and, from the account of several historians, indicates that his decisions were easily influence by his cabinet and members of Congress. His Secretary of State, John Quincy Adams, seemed to have the most influence over the President and he was one of the strongest opponents of becoming involved in Greece, whether it by military or diplomatic means. All historians that have analyzed Monroe's decision making seem to agree that Adams both influenced the President and also opposed the situation in Greece out of some ulterior motive. Repousis attributes Adam's motives to matters of diplomacy and simple economics, as well as his own personal political interests. ${ }^{116}$ Chapman broke from this interpretation and linked Adams' motives to personal financial interests, a free market capitalistic ideology, and ties to Col. Perkin's Opium Trade. ${ }^{117}$ Chapman's analysis seems to be the most on target, not only was this a clearly confusing decision on the President's part, but also it made very little diplomatic and political sense to other European powers.

Marquis de Lafayette expressed this bafflement best in a letter to Henry Clay, saying that the fight in Greece was a good cause, it adhered to not only fighting for

${ }^{115}$ Angelo Repousis, “'The Cause of the Greeks:' Philadelphia and the Greek War for Independence, 1821-1828," The Pennsylvania Magazine of History and Biography 123, no. 4 (October 1999): 338.

${ }^{116}$ Ibid., 338-340.

${ }^{117}$ Michael E. Chapman, "Pragmatic, ad hoc Foreign-Policy Making of the Early Republic: Thomas H. Perkins's Boston-Smyrna-Canton Opium Model and Congressional Rejection of Aid for Greek Independence," International History Review 35, no. 3 (2013): 458-461. 
liberalism and protecting Christianity, but also it was a humanitarian cause in light of the Turkish atrocities. ${ }^{118}$ Furthermore, Lafayette said that France, Great Britain, and other major Europeans had begun to lend aid; an American presence would not be unwelcome. ${ }^{119}$ Lafayette went on to say:

I have been anxiously waiting for the arrival of the two private New York frigates and persisting in the opinion that the presence of an American squadron on those seas affords honorable opportunities, consistent with the rules of neutrality, to render essential services. And, indeed, such I have found the popular feeling in the United States. Such is now the feeling in Europe, that every service rendered to those people would be looked upon with very favorable constructions..$^{120}$

Clearly, the actions of the United States were viewed as unusual; France and the rest of Europe found the American definition of neutrality as overly cautious. To at least Lafayette, the Greek War was a universal cause that all nations should be able to agree with and he did not understand why the United States Secretary of State, Henry Clay, did not simply send some sort of envoy representing the United States government.

Aside from this confusion on what exactly America's position was in the conflict and taking up a policy of neutrality, the Secretary of State's diplomatic activity in the Mediterranean in 1825 made the situation more perplexing. The diplomatic community was confused as to what exactly the United States meant by "neutral." In October of 1825, Henry Clay, then Secretary of State, sent a representative, John Rodgers, to Turkey and Greece to conference with the Ottoman

\footnotetext{
${ }^{118}$ Edward Meade Earle, "American Interest in the Greek Cause, 1821-1827," The American Historical Review 33, no. 1 (1927): 52-54.

${ }^{119}$ Marquis de Lafayette to Henry Clay, 28 May 1826, in America in Greece: A traditional Policy, ed. David M. Robinson (New York, NY: Anatolia Press, 1948), 55.

${ }^{120}$ Ibid.
} 
government. Rodgers reported troop positions and recent battles between the Greeks and Turks, and described how there is an opportunity to negotiate a trading treaty with the Ottoman Sultan. ${ }^{121}$ Furthermore, Rodgers provided context on the current conflict and said that the public was not truly aware of the situation in Greece and that the Greeks were hopelessly outmatched. ${ }^{122}$ This letter is troubling because, despite having a supposedly neutral position on the conflict, the Secretary of State's office was closely monitoring the progress of the war and has been talking directly with the Ottoman government and their military commanders. Additionally, the United States government was exploring trade options with the Turks, and was aiming to negotiate an eventual trade treaty. Despite the apparent "neutrality" of the United States government, it is highly suspicious that the United States would look to monitor a war they swore off, seek a trading presence in the Mediterranean when the United States refused to send a ship to protect non-military vessels, and look to expand commerce with a country that President Monroe had hoped would lose its hold on Greece. Whatever the true interest of the United States was, it was certainly not maintaining neutrality and remaining distant from the conflict. There was, at the very least, a deep economic concern about United States commerce with Turkey and it seems the United States wanted to protect as well as strengthen its current deals with the Ottoman Empire.

In fact, evidence suggests that prominent politicians had questionable investments that might have incentivized them to strengthen relations with Turkey

\footnotetext{
${ }^{121}$ John Rodgers to Henry Clay, 14 October 1825, Dispatches from U.S. Ministers to Turkey, 1818-1906, US National Archives, Waltham, MA.

${ }^{122}$ Ibid.
} 
and avoid the Greek conflict. In a letter from John Quincy Adams to Col. Thomas H. Perkins in 1827, the President thanks the merchant for his financial advice, and for introducing him to Col. Israel Thorndike. Adams goes on to discuss his appreciation for Perkins' assistance in helping him invest in Thorndike's business venture, and how he values the long friendship he has had with Perkins. ${ }^{123}$ This letter indicates that, despite his job of running the country, Adams was conducting private business and had deep financial connections with several Boston merchants and businessmen. Furthermore, there was even an indication of a personal relationship as Adams referred to Perkins as both a friend and business associate. While, on the surface, it seems to not really be a big issue, but it becomes more problematic when considering the business and investments in which both Thorndike and Perkins were involved.

Perkins, for instance, was deeply invested in the Chinese Canton Trade and had gradually moved his entire business over to the buying and selling of Opium to the Chinese people. He purchased all of his opium from the Ottoman Empire and, by 1820 , depended entirely upon the "good will" of the Turks to continue his business. ${ }^{124}$ In addition to Perkins' investments, upon closer examination of Thorndike, it turns out that both Perkins and Thorndike were long time friends and had invested in many projects together, including the local Massachusetts Bay Canal Corporation, and the oversea China Trade. ${ }^{125}$ Thorndike had a flourishing

${ }^{123}$ John Quincy Adams to Col. Thomas Handasyd Perkins, 3 October 1827, microfilm roll 2, folder 7, Thomas H. Perkins Papers, Massachusetts Historical Society, Boston, MA.

${ }^{124}$ Carl Seaburg and Stanley Patterson, The Merchant Prince of Boston: Colonel T.H. Perkins, 1764-1854 (Cambridge, MA: Harvard University Press, 1971), 298-301, 313.

${ }^{125}$ Ibid., 283-285. 
mercantile business between South America and Canton, China, and often used Perkins' ships to move his goods between Canton and other ports of interest. ${ }^{126}$ Hence, by all accounts, Perkins and Thorndike appear to be heavily invested in each other's financial success.

Since John Quincy Adams seems to have been deeply involved with Perkins and Thorndike both socially and financially, his opposition and treatment of the Greek War for Independence seems to be guided by personal interests, not by the actual needs of the country. When the issue of America's interest in the War is put into question and the relationship between the John Quincy Adams Administration, The Ottoman Empire, and the Canton Trade is examined, the entire dynamics of American foreign policy change. The traditionally accepted narrative of America's neutrality during the conflict becomes complicated. It becomes less likely the United States was trying to uphold the Monroe Doctrine and avoiding war out of the interest for diplomatic and political stability. If Adams, the strongest opponent to the conflict, was financially connected to the Ottoman Empire, the nation that America would have been at odds with, then his foreign policy changes from protecting the state to protecting his wallet. Thus does Adams' involvement with Perkins and Thorndike denote a conflict of interest between his personal financial stakes and his responsibilities as President of the United States.

${ }^{126}$ J.D. Forbes, Israel Thorndike: Federalist Financier (New York, NY: Exposition Press, 1953), 36-39 and 45-49. 


\section{Part III: Perkins and the Boston Oligarchy}

For one to truly understand the influence Thomas H. Perkins and his associates had on government officials and the shaping of American foreign policy, one must understand the business and investments of this individual. Col. Thomas Handasyd Perkins, born December 15, 1764 and died January 11, 1854, was a member of the Boston Brahmin families of Massachusetts during the early years of the United States. He was a prominent merchant and businessman that accumulated most of his wealth from the Chinese Trade by first selling furs and then opium. Aside from his financial ties, Perkins was also a philanthropist and, essentially, a "political boss". He was also an ardent Federalist for most of his life.

Col. Thomas Perkins' business was initially a joint venture between himself and his older brother, James Perkins. Their major joint venture was participation in the Canton Trade, using investments from Ephraim Bumstead and several others, the brothers were able to send a ship in 1803 to Canton and begin trading with the Chinese people. ${ }^{127}$ In order to begin a successful trading relationship with Canton, Perkins and his investors purchased furs from the American Northwest and additionally used specie (gold and silver coinage) to make up any monetary shortcomings. They then shipped the furs and specie to Canton to either purchase spices and tea, or sell the furs at a marked up price. ${ }^{128}$ This initial investment let the Perkins brothers enter the market and allowed for them to accumulate wealth pretty rapidly. In addition, Perkins also worked out of

${ }^{127}$ Account Book, 25 January 1803, microfilm reel 5, volume 33, Perkins Papers, E. Bumstead \& Co., Massachusetts Historical Society, Boston, MA.

${ }^{128}$ Carl Seaburg and Stanley Patterson, The Merchant Prince of Boston: Colonel T.H. Perkins, 1764-1854 (Cambridge, MA: Harvard University Press, 1971), 155-157. 
multiple ports, not only was he based in Boston with multiple investors within the community, but also he commissioned the ship the Patterson with four other investors out of Providence harbor. ${ }^{129}$ Using his nephew (also adopted son), John Cushing, as the representative "supercargo" agent in Canton, Col. Thomas Perkins purchased three "factories" in Canton to have both a base of operations and a place to store and prepare products. ${ }^{130}$ Thus, the entire wealth and operation of Perkins' company depended upon foreign investments and his ability to access them. If Perkins was to lose contact with these factories, then he could suffer a possible financial loss.

Early in Perkins' mercantile career, he had a diversified trading system between all regions of the world. Despite briefly practicing the slave trade in the late 1790 s, Perkins mainly traded furs, lumber, flour, fish, horses, and other miscellaneous products for various clients. ${ }^{131}$ Essentially, his shipping industry was in the business of moving all things around the globe. ${ }^{132}$ Once he had accumulated enough wealth, he and his brother decided to focus on a main "staple" and enter the Canton trade with fur. He was only further encouraged to do this as trade in the West Indies began to falter and the potential return of investment (over a $\$ 300,000$ investment at the time) in Canton became more and more promising. ${ }^{133}$ Thus, at this point in Perkins' career (1803-1807) his investments were diverse and he could rely upon one business venture if the other came up short. Perkins developed three main categories of trade: short-term speculation (focusing on West Indian trade), medium-term speculation (focusing on Europe and delivering raw or finished products), and long-term trade (the China trade, creating a long distance base

\footnotetext{
${ }^{129}$ Ibid., 156-157.

${ }^{130}$ Ibid., 165-166.

${ }^{131}$ Ibid., 145.

${ }^{132}$ Ibid.

${ }^{133}$ Ibid., 161.
} 
with long journeys between New England, the Northwest fur trade, and Canton). ${ }^{134}$ It was this long-term investment that brought in most of Perkins' later wealth and would push his business to focus primarily on Canton.

Perkins' business in Canton began to change shortly after the War of 1812. Noticing a diminishing demand for furs and specie, and a rapid rise in value for opium and quicksilver (mercury), Thomas began to follow the market. He selected Turkish opium because India had been monopolized by the British and there was a high demand for that type of opium in Northern China. ${ }^{135}$ Using the advice of John Perkins Cushing, monitoring the situation in Canton, Perkins heavily invested in opium and noticed a significant increase in return. This sort of rapid change in trading interests demonstrates two important features about Col. Thomas Perkins as a businessman and about his business. First, he paid extremely close attention to the market and wanted a completely safe return on investment. Opium was a "safe" investment because it was a high demand product and other commodities were losing profitability, he wanted to minimize risk. Second, Perkins' further investment into the opium trade and dependence on higher and higher profit margins would make it exceedingly difficult for him to withdraw from the market if something happened.

Another unique consideration of Perkins' business model is his investment in the iron mining industry during the War of 1812. Due to the essential shut down of trade because of the British blockade, Perkins was unable to further his business dealings in Canton or anywhere else outside of the country. As a result, Perkins was forced into "laying by," essentially resorting to not-so-profitable business ventures within the United

\footnotetext{
${ }^{134}$ Ibid., 145-146.

${ }^{135}$ Ibid., 265-266.
} 
States to continue his income. ${ }^{136}$ In Perkins' case, he decided to invest in the iron mining industry in the state of Vermont. It was a grueling task and Perkins was able to yield some income, especially from the United States government as the iron he mined was used to create cannonballs for the war. ${ }^{137}$ This falling back on crude but ultimately "safe" measure for continuing business demonstrates both a weakness in Perkins' business and a personal characteristic of Perkins. First, Perkins' business was based overseas and he depended upon the freedom of sea travel to ensure a profits; any war or trade embargo could easily threaten that prosperity. Second, Perkins, like any good businessman, did not like uncertainty, and always wanted to be making money, even if it was a small profit. His investment in the iron industry was a desperate safety measure that kept him "afloat," and gave him some sort of economic certainty that he could depend upon.

This sort of cautionary investing and constant need for certainty can even be viewed in his business affiliations and social position in Boston. For instance, the Perkins family tended to keep the business a "family business" by either hiring children and other relatives or marrying their children into families they regularly did business with. Col. Thomas Perkins even made sure that his close family friends and business associates all lived in the same neighborhoods in Boston; this familial "grouping" lasted about two generations. ${ }^{138}$

Perkins and his associates also built a network of familial relations both in business and in politics, not only did it ensure trustworthy partners but also it gave Perkins the ability to influence Boston society and politics. For instance, Perkins formed

\footnotetext{
${ }^{136}$ Ibid., 236-239.

${ }^{137}$ James Elliot Cabot, Extracts from Letterbooks of J \& T H Perkins et al. (1886), 212-213.

${ }^{138}$ Carl Seaburg and Stanley Patterson, The Merchant Prince of Boston: Colonel T.H. Perkins, 1764-1854 (Cambridge, MA: Harvard University Press, 1971), 142.
} 
several partnerships with the Higgins family, another merchant family in Boston, because Thomas' brother had married into that family. ${ }^{139}$ Col. Thomas Perkins also secured his overseas assets with family members, in Canton John Perkins Cushing served as Perkins' on-the-ground representative that oversaw all transaction. Also, Cushing was Thomas' nephew and Thomas also raised Cushing as an adopted son of sorts. ${ }^{140}$ Senator Harrison Gray Otis was a long-time friend of Thomas H. Perkins. They had known each other since childhood; both helped each other in both politics and business, especially during the attempt to secede. ${ }^{141}$ Thomas H. Perkins Jr. worked on many of his father's ships and eventually took over a large portion of the business along with the Cabots. ${ }^{142}$ Samuel Cabot, a prominent business associate, also married Col. Thomas Perkins' daughter, Eliza. ${ }^{143}$ Perkins assigned his brother's nephew, Frederick Paine, to be a special messenger that was to go between Perkins and Cushing. The Cabot family became particularly involved with the Perkins family. They formed a formal business partnership in 1821 and became joint investors in the textile industry only a few years later. ${ }^{144}$ The Thorndike family also became close associates not just through their dealings, but also through tight bonds of friendship. Specifically, Thorndike's son was married to Otis' daughter and therefore made him as equally influential as Perkins when it came to national and local politics. ${ }^{145}$

${ }^{139}$ Ibid., 146.

${ }^{140}$ Ibid., 163 and 138.

${ }^{141}$ Ibid., 256 and 31-32.

${ }^{142}$ Ibid., 245 and 340.

${ }^{143}$ Ibid., 235-236.

${ }^{144}$ Ibid., 300 and 311-313.

145 J.D. Forbes, Israel Thorndike, Federalist Financier (New York, NY: Exposition Press, 1953), 71. 
Perkins had countless connections across Boston both in politics and in business, whether it was through mutual friends or direct family ties, Perkins built an "empire" through family blood and money. He staffed his business with the only people he could trust, his family, and kept his personal ties both happy and close. In fact, Perkins was so selective and cautious about whom he trusted that he only placed very close family members into managerial positions of his business, such as John Cushing (basically a son), Sam Cabot (son-in-law), and T.H. Perkins Jr. (his direct son). Thus, Perkins was a businessman that always wanted a safe bet and placed people he could absolutely trust in key positions of influence and responsibility.

Aside from his familial and friendly ties, Perkins also tended to associate, or at least work, with individuals that helped expand his business both financially and geographically. The Megee family, for instance, was influential in Rhode Island and had some level of control over the goods shipped in and out of Providence harbor. When Perkins began to establish the Canton trade, he included William Megee into the venture. ${ }^{146}$ The Megee family and Perkins family had a deep personal and business relationship; Col. Thomas Perkins and his wife often spent time with William Megee and Mrs. Megee while conducting countless deals that spanned over twelve years ${ }^{147}$ Although William Megee ended up falling upon hard times, Perkins worked often enough with Megee to establish a formal business presence in Providence harbor. ${ }^{148}$ Whether or not his relationship with Megee was genuine or simply a means to an end, what can be said for certain is that Perkins' association with Megee extended his financial presence to

\footnotetext{
${ }^{146}$ Carl Seaburg and Stanley Patterson, The Merchant Prince of Boston: Colonel T.H. Perkins, 1764-1854 (Cambridge, MA: Harvard University Press, 1971), 149-150.

${ }^{147}$ Ibid., 180-181.

${ }^{148}$ Ibid.
} 
another state and gave him more economic influence in the region of New England as a whole.

Perkins also often kept in contact with his competitors. During the early years of the Fur and Canton Trade, his rivals were the Lymans and the Lambs. ${ }^{149}$ In 1807 , Perkins caught word of Theodore Lyman's potential retirement and Perkins decided to approach this competing merchant with a deal. The negotiations proved to be fruitful for Perkins. In exchange for $\$ 8,000$, he received the Lyman's ship, the Vancouver, and the promise to not send any ships to the Northwest. ${ }^{150}$ The Lambs also formed a partnership with the Perkins brothers and thus gave Col. Thomas Perkins an essential monopoly over the Northwest-Canton fur trade. In addition, it gave Perkins partial dominion over Maine's ports because Lyman was based out of Boston, Massachusetts and York, Maine, and he was contemplating retirement. ${ }^{151}$ Thus, through the negotiation of deals as well as partnerships and staying in contact with his competition, Perkins was able to expand his fleet, compete in Maine, and essentially establish a monopoly on the Canton fur trade in New England.

Col. Thomas Perkins, through his familial connections, rubbing of elbows, strategic partnerships, and friendly relations with other merchant families, established an interconnected economic empire that dominated most of New England and reached far across the globe. He secured his assets with trusted individuals and backup investments, and he always made sure to have someone on the "inside" to advocate for his interests. This ruthless and calculated behavior built up Perkins' wealth and gave him unprecedented influence throughout New England. It was by implementing these same

\footnotetext{
${ }^{149}$ Ibid., 181-182.

${ }^{150}$ Ibid., 182.

${ }^{151}$ Ibid.
} 
techniques and always striving to have a secure and stable future that Perkins expanded his influence and power into and throughout politics. This "King of Opium" blurred the lines between what was business and what was politics. Using economics to control politics and vice versa, Perkins was able to protect and expand his investments, while secretly writing public policy that was not in the interest of the general population.

Boston's political structure in the Early Republic was less of a democracy and more of an elitist oligarchy where the economically well-to-do and old familial political dynasties sat on top. This system thus enabled Perkins to utilize his connections to secure his own interests. He also knew how to play the game in Boston politics and even set the "rules" that turned Boston into a Federalist stronghold well into the Ante Bellum Period. Perkins' influence was so pervasive that he was able to capture the ear of national politicians and bend them to his will.

Before discussing the intricacies of Perkins' political network, it is important to note his source of popularity in Boston and how he maintained an "uncontroversial" status in the eyes of common Bostonians. Specifically, Col. Thomas Perkins and his brother James were generous philanthropists and received much praise from the general public of Boston. James and Col. Thomas Perkins were longtime members of the Boston Athenaeum and usually helped sponsor various libraries throughout Boston. Upon James' death in 1822, the brothers donated funds to the Boston Athenaeum and even handed over James' old estate to the library so as to better facilitate the growing collection. ${ }^{152}$ Due to Perkins' contributions, the Boston Athenaeum was able to expand, leading to the eventual establishment of the Boston Museum of Fine Arts decades later.

\footnotetext{
${ }^{152}$ Ibid., 301-302.
} 
In 1825, Perkins decided to help organize and fund the building of the Bunker Hill Monument, lending his expertise in finance, Perkins helped plan out the logistics for the project. He helped supply the money and got the society to acquire a granite mine to fund the project; curiously, he also purchased the mine and built the rail to it. ${ }^{153}$ Perkins also assisted the planning of many parades, and even helped host President John Adams in 1798 and President James Monroe in $1817 .{ }^{154}$ Philanthropic gestures like these kept Perkins uncontroversial and viewed as a good influence on the city of Boston. Not only did this benefit Perkins in the public eye, but they also advanced him personally, as he gained some profit from the Bunker Hill project and was able to gain access to two sitting presidents.

Col. Thomas Perkins also served as a public servant; in 1797 he was elected as a "fireward" in Boston. ${ }^{155}$ He served as a "vote distributor" and handed out ballots to voters during election time. ${ }^{156}$ This position was a form of open ballot voting, which put voters in a situation where their employers could see how they voted. As a result of this lack of anonymity, voters were silently coerced into voting against their own interests. Thus was Perkins openly participating in an election system that controlled the way people voted. Furthermore, Perkins helped organize and lead a committee that would select candidates that would be elected to Boston's city government. Intriguingly, all of the candidates that were selected were Federalists and Perkins was one of these candidates. ${ }^{157}$ This sort of unusual unanimity for a particular party and the holding of surreptitious committees indicate some sort of foul play in the democratic process, and an attempt to

\footnotetext{
${ }^{153}$ Ibid., 329-332.

${ }^{154}$ Ibid., 273-277.

${ }^{155}$ Ibid., 121-122.

${ }^{156}$ Ibid., 123.

${ }^{157}$ Theodore Lyman, "Statement of Facts,” Columbian Centinel, May 14, 1796.
} 
dominate the government of Boston, if not Massachusetts. By all accounts, Perkins was deeply involved with this committee and the Federalist Party, the faction that seemed to be pushing for this dominance. Such a rigging of the democratic process indicates that Perkins was primarily interested in protecting his own assets, and was willing to manipulate the local government to get his way.

Perkins remained a longtime member of the Federalist Party and took on a leadership role at several points during his life. Serving as a member of the Central Committee of Massachusetts, Perkins essentially had the power and authority to select the members of town committees throughout Massachusetts. Unsurprisingly, the majority of representatives sent to the General Court of the commonwealth were Federalists. ${ }^{158}$ Perkins even ran for a representative position in the state legislature and, predictably, won the seat to represent Suffolk County. ${ }^{159}$ This ease in controlling the vote and the ability to obtain a political office with little worry demonstrates how powerful and influential both Perkins and the elite families of Boston were in the Commonwealth of Massachusetts. Even in years of unpopularity, the Federalist Party remained in power and, as long as Perkins stayed amongst its leading members, he could control the entire political structure of the commonwealth.

Hence if Perkins was able to influence the Federalist Party, then the question becomes what degree of influence did he have? Starting from at least the late 1790s, Perkins had access to prominent political figures and was able to help host large events on behalf of the Federalist Party. In August of 1798, President John Adams visited Boston and was welcomed by prominent members of the Boston community as well as

\footnotetext{
${ }^{158}$ Carl Seaburg and Stanley Patterson, The Merchant Prince of Boston: Colonel T.H. Perkins, 1764-1854 (Cambridge, MA: Harvard University Press, 1971), 169-170.

${ }^{159}$ Ibid.
} 
Federalist Party leaders. This welcoming party organized a tour around the town, several balls, and a parade in John Adam's honor. Col. Thomas Perkins was amongst the organizers and he lead the parade that honored the President. ${ }^{160}$ Furthermore, the parties and celebrations held in honor of the President were described as lavish and lively, to Joseph Dennie, the Bostonians celebrated like the French. ${ }^{161}$ This sort of accessibility indicates that Perkins, very early on in his life, was prominent enough within the Federalist Party to lead a portion of the welcoming celebration for the President.

While this passage does not indicate whether or not John Adams knew Perkins at the time, there is evidence to suggest that Perkins and Adams had some sort of social relationship. In a letter from Adams to Perkins, the former president thanks the merchant for his gift of grapes and indicates that there is some sort of friendship between the two figures. ${ }^{162}$ Such a letter goes beyond simple political association and indicates at least a mildly personal relationship. Thus, Perkins, through this association, had top leadership in the Federalist Party and could call out favors from individuals for political reasons.

This realization makes it only clearer that Perkins and his close associates, specifically H.G. Otis, were political bosses and, through the "Central Committee" system, they had engineered the appearance of democracy, but really implemented a Federalist Party web of favors. ${ }^{163}$ Otis, in a letter to Woodbury Storer, indicates that they had successfully systemized the Federalist Party into the electoral process

${ }^{160}$ Ibid., 124-126.

${ }^{161}$ Robert Winthrop, Robert Winthrop Jr., Charles Dean, Edward Hale, and George Ellis, “March Meeting, 1880. Letter from Joseph Dennie, Jr.," Proceedings of the Massachusetts Historical Society 17 (1879-1880): 364.

${ }^{162}$ John Adams to Thomas H. Perkins, 16 September 1825, microfilm reel 2, volume 5, Thomas H. Perkins Papers, Massachusetts Historical Society, Boston, MA.

${ }^{163}$ Carl Seaburg and Stanley Patterson, The Merchant Prince of Boston: Colonel T.H. Perkins, 1764-1854 (Cambridge, MA: Harvard University Press, 1971), 168-170. 
and that he viewed democracy as something "wild" that had "cursed the country."164 Thus, to Perkins and Otis, democracy was something to be feared because of its uncertainty and, if one had the chance, one should seek to manipulate it and permit select individuals to run the government. What is more telling about Perkins is his placement in this Central Committee system. Since Perkins, Otis, and other Federalists organized this system, they actively made sure the Federalists in each county of Massachusetts were both represented and had the necessary support. 165 In effect, this active control and support of the Federalist political system in Massachusetts made Perkins exceedingly influential. Candidates were approved by him, each Federalist politician owed their status to him, and Perkins knew every Federalist politician in the commonwealth.

This influence was often acted upon by Perkins through punishing and rewarding Federalist politicians across the Commonwealth; no office was too big or too small for him to influence. In 1807, the Boston Federalists became outraged by Jefferson's Embargo with Europe and, lead by Gore, Otis, Revere, and Perkins, gathered prominent members of the party in Fanueil Hall. These members included John Adams, John Quincy Adams, Robert Treat Paine, and several others. ${ }^{166}$ David Parish reported how the Boston merchant community was concerned about their economic stability, how the China trade was essentially going to be strained, and feared further economic stunting because the embargo might plunge the United

${ }^{164}$ Harrison G. Otis to Woodbury Storer, 29 August 1804, volume 18, Miscellaneous Bound Papers, Massachusetts Historical Society, Boston, MA.

${ }^{165}$ Carl Seaburg and Stanley Patterson, The Merchant Prince of Boston: Colonel T.H. Perkins, 1764-1854 (Cambridge, MA: Harvard University Press, 1971), 168-170.

${ }^{166}$ Ibid., 185. 
States into war. ${ }^{167}$ Perkins, Otis, and the other leaders of the Boston Federalist Party had decided to vehemently oppose the embargo and were pushing other members of the party to join them. John Quincy Adams disagreed with the Federalist leadership and he was essentially ostracized from the party. To add insult to injury, John Quincy Adams attended a Democratic-Republican Meeting a few days after the event. ${ }^{168}$ Although Adams rejoined the Federalist after the dispute, Perkins did not forget this transgression.

In 1808, Perkins and Timothy Pickering decided to support a business associate, James Lloyd, for Adams' seat in Congress. With a simple nod and wink, Adams lost his seat and a virtually unknown politician was placed into office. James Lloyd was someone Perkins had incorporated into his business practices. ${ }^{169}$ What was most revealing about the transition was not just the fact that it happened to John Quincy Adams, the son of a former president and Founding Father, but also the way in which this transition was conducted. In a letter from Christopher Gore to Rufus King, John Quincy Adams is described as being ignored by his fellow Bostonians and essentially becoming alienated. ${ }^{170}$ Perkins and the Federalist Party not only forced Adams from office, but they also turned the population of Boston against Adams and ostracized him both socially and politically. This sort of influence that Perkins had over someone who was the son of an essential American icon, while continuing a cordial relationship with John Adams Sr., is both unprecedented

\footnotetext{
${ }^{167}$ James Elliot Cabot, Extracts from Letterbooks of J \& T H Perkins et al. (1886), 148.

${ }^{168}$ Carl Seaburg and Stanley Patterson, The Merchant Prince of Boston: Colonel T.H. Perkins, 1764-1854 (Cambridge, MA: Harvard University Press, 1971), 185-186.

${ }^{169}$ Ibid., 191-192.

${ }^{170}$ Christopher Gore to Rufus King, 16 June 1808, letter box 12, folder 2, Rufus King Papers, New York Historical Society, New York.
} 
and telling of Perkins power in Massachusetts alone. Perkins had enough influence to punish and reward his political peers on a whim, and worked to control key politicians so as to protect his business.

The Adams family is the best example of this "stick and carrot" relationship, and how Perkins kept key figures dependent and grateful for his rewards while cautious and heeding of his punishments. In 1827, Adams, Everett, and Webster turned to Perkins for political support during the run up to the 1828 election. Perkins rewarded the politicians by mobilizing his network of associates, offering Adams financial investments, and encouraging the entire Federalist Party to support Adams in his re-election. ${ }^{171}$ This sort of political influence was powerful, Perkins had the ability to deliver entire states to presidents in elections and he could easily thwart or encourage the rise of any up and coming Massachusetts politician.

This influence demanded so much respect that Perkins could command national politicians to attend events and ceremonies all while capturing their ear to "ask" that they protect a certain aspect of his business empire. For instance, during the 1825 ceremony for laying the cornerstone of the Bunker Hill Monument (a project that was partly funded by Perkins), President John Quincy Adams became a part of the dedication ceremony. He did not serve a central role in the ceremony, but rather served as a notable figure to complement the main guest of honor, Marquis de Lafayette. ${ }^{172}$ In 1817, Perkins served as the main welcoming party for the newly elected president, James Monroe, during his visit in Boston. Organizing the entire

\footnotetext{
${ }^{171}$ Carl Seaburg and Stanley Patterson, The Merchant Prince of Boston: Colonel T.H. Perkins, 1764-1854 (Cambridge, MA: Harvard University Press, 1971), 350-351.

${ }^{172}$ Ibid., 323.
} 
visit with his Federalist friends, Perkins made speeches welcoming the President to Boston and paraded the President around the city. ${ }^{173}$ Celebrating Independence Day with each other and hosting several dinners in Monroe's honor seemed to be more for the benefit of Perkins than Monroe. ${ }^{174}$ In fact, Perkins even had the honor of having President Monroe sit in the same pew as him during Sunday church services. ${ }^{175}$ Ultimately, this grand welcoming turned out to be one giant pitch to the President to invest into his iron works in Vermont as well as address other aspects concerning Perkins' business. ${ }^{176}$

Directly after visiting Boston, the President did go to Vermont and stopped at the Vergennes iron works that Perkins owned. ${ }^{177}$ Despite the fanfare, Monroe ultimately decided against investing in Perkins' iron works. ${ }^{178}$ While Perkins might not have received what he wanted, this affair demonstrates just how influential Perkins was in the Early Republic. He summoned the President to Boston to both listen to a business deal and to use the opportunity to boost his own image in the eyes of his fellow Bostonians. This visit to Boston proves that Perkins had the ability to affect the federal government and influence national politicians. If such an influence were used for purposeful means then Perkins, in theory, could directly affect national policy.

${ }^{173}$ Aaron White, Diaries, 2 July 1817, Massachusetts Historical Society, Boston, MA.

${ }^{174}$ Carl Seaburg and Stanley Patterson, The Merchant Prince of Boston: Colonel T.H. Perkins, 1764-1854 (Cambridge, MA: Harvard University Press, 1971), 275-277.

${ }^{175}$ Eliza Susan Quincy, Diaries, 6 July 1817, Quincy, Wendell, Holmes \& Upham Family Papers, Massachusetts Historical Society, Boston, MA.

${ }^{176}$ Carl Seaburg and Stanley Patterson, The Merchant Prince of Boston: Colonel T.H. Perkins, 1764-1854 (Cambridge, MA: Harvard University Press, 1971), 276-277.

${ }^{177}$ E.P. Walton, Records of Governor and Council of the State of Vermont (Montpelier, VT: Steam Press of Joseph Poland, 1880) VIII:448.

${ }^{178}$ Carl Seaburg and Stanley Patterson, The Merchant Prince of Boston: Colonel T.H. Perkins, 1764-1854 (Cambridge, MA: Harvard University Press, 1971), 276-277. 
Outside of just politics, Perkins also had the ability to influence the judicial system and protect individuals that were either important to his business or the Federalist Party. For instance, Thomas Oliver Selfridge, a loyal member of the Federalist Party and a lawyer in Boston, shot and killed Charles Austin, a Democratic-Republican Boston merchant, over a legal dispute that stemmed from an unpaid bill at Jefferson's Tavern, Perkins was able to ensure Selfridge was not convicted of this crime. ${ }^{179}$ According to both Seaburg and the records of the Massachusetts Supreme Court, the entire grand jury in Selfridge's case was composed of well-known Federalists. ${ }^{180}$ Curiously, Thomas H. Perkins, the ipso facto leader of the Federalist Party in Boston, was the foreman of the jury in the case. ${ }^{181}$ Instead of being tried for murder, Perkins, in his testimony, argued that it might qualify as manslaughter and should be considered a case of self-defense. ${ }^{182}$ The final verdict, after fifteen minutes of deliberation, was "not guilty." How fortunate it was for Selfridge that the entire jury seemed to be composed of political allies. ${ }^{183}$

Perhaps it is coincidence that the jury just ended up being composed of fellow Federalist and Perkins just so happened to have served on this jury. The events surrounding the case, however, seem to suggest that there was something intentional going on. When the prosecution placed three people on the stand it

${ }^{179}$ Ibid., 172-175.

${ }^{180}$ Thomas Lloyd, George Caines, and The Massachusetts Supreme Judicial Court, The Trial of Thomas O. Selfridge, attorney at law, before the Honorable Isaac Parker, Esquire. For Killing Charles Austin, On the Public Exchange, in Boston, August 4, 1806 (Boston MA: Russell and Cutler, 1807), 7-8.

${ }^{181}$ Ibid.

182 Ibid.

${ }^{183}$ Carl Seaburg and Stanley Patterson, The Merchant Prince of Boston: Colonel T.H. Perkins, 1764-1854 (Cambridge, MA: Harvard University Press, 1971), 174-176. 
seemed almost certain that Selfridge would be convicted. When the defense had its turn, they produced twice as many witnesses (all of whom were Federalists) that provided testimonies that were completely opposite the prosecution and seemed to push toward the notion of "self-defense" on Selfridge's part. ${ }^{184}$ Thus, it is almost certain that Perkins and the rest of the Federalist Party had mobilized to not only protect one of their own but also rig an entire court case. Perkins' protection of Selfridge demonstrates a few important things; first, Perkins had the funds and influence to easily rig a court case. Second, the motivation for this help was, at a bare minimum, political and a way for Perkins to build up his "clientage." Selfridge was a fellow Federalist with a law degree; this sort of individual could become a great asset in politics and, at the very least, Perkins could gain his loyalty to expand his own business, and demonstrate to other Federalists the possible rewards Perkins could provide, i.e. avoiding prosecution.

Another example of Perkins utilizing a system of favors and loyalties was his involvement in the Bunker Hill Monument project. Daniel Webster, both a Congressman and member of the committee for the project, owed Perkins a large debt. Since Webster was thus loyal to Perkins' wishes, Perkins was able to indirectly influence William Tudor, a leading organizer of the monument committee. This gave Perkins his proverbial "foot in the door", enabling him to influence the project. 185 Perkins would not only become one of the key organizers of the project, but also he would serve as the main supplier of stone to the monument, thus Perkins was given the chance to profit off a philanthropic project.

\footnotetext{
${ }^{184}$ Ibid., 174-175.

${ }^{185}$ Ibid., 318.
} 
Specifically, Perkins was able to construct the Granite Railway between the quarry and the building site. It was the first railroad in America and a large chunk of the funding for this came from the Massachusetts Commonwealth legislature (which Perkins was a member of at the time). ${ }^{186}$ He owned the majority of the shares in the railway and eventually expanded parts of the rail system. By no means was this railway a great moneymaker for Perkins, but it did bring in a respectable profit for the old merchant. ${ }^{187}$ It seems that whenever Perkins used his resources to help other individuals, it was either out of party loyalty and/or the expectation of receiving some sort of return favor. Thus, it is not inaccurate to describe Perkins as a power broker and financial boss of the entire Boston area, he never did anything for free and many of the major projects in the city had to go through him.

When considering his involvement in the Greek War for independence, one can see same sort of quid pro quo relationship and understand why major supporters of the Greek War for Independence suddenly lessened their support for the cause. Edward Everett, for example, wrote to Perkins in December of 1823 and, despite Perkins having been appointed to the Greek Committee, asked why Perkins had published the article "A Merchant" in the Daily Advertiser, in which Perkins spoke out against the war anonymously. Everett demanded that Perkins step up his contribution to the cause and appealed to their friendship for understanding. ${ }^{188}$

${ }^{186}$ American-Rails.com, “The Granite Railway, First Chartered Railroad,” Railroad History, accessed November 27, 2016, http://www.american-rails.com/granite-railway.html

${ }^{187}$ Carl Seaburg and Stanley Patterson, The Merchant Prince of Boston: Colonel T.H. Perkins, 1764-1854 (Cambridge, MA: Harvard University Press, 1971), 331-335.

${ }^{188}$ Edward Everett to Thomas H. Perkins, 19 December 1823, microfilm box 2, folder 5, Thomas H. Perkins Papers, Massachusetts Historical Society, Boston, MA. 
Oddly, Everett felt obligated to co-sign the letter with the rest of the committee members and to make the letter "official."

While we do not have the response to this letter, we can only guess that it was not favorable, for a letter from a couple of years later demonstrates a very different dynamic between these two individuals. In the 1826 letter from Everett to Perkins, Everett made some perfunctory statements about "complying with your request relative to a Newspaper" and generally discussed matters of state. ${ }^{189}$ In a very roundabout way, Everett brought up the Greek War for Independence and asked, point-blank, if Perkins would help donate funds to the Greek cause so as to support Dr. Samuel G. Howe, an American volunteer on the Greek frontlines. Everett went onto say how he had been drained of his funds and would be willing to gradually reimburse Perkins if he were to donate some funds. ${ }^{190}$ What is most shocking about this conversation, aside from the change of tone from upset to almost begrudged begging, is that Everett was a United States Congressman at this time. Thus, Everett, an elected official that should only be beholden to the public and had legal authority, was essentially paying respects to Perkins and seemed quite dependent upon his good will. Clearly affected by the financial demands of the Greek Cause, and possibly the recent election, Everett was in a tough spot and, despite Perkins' earlier opposition to the conflict, had to ask a favor of him. Whether or not Everett was truly desperate, it can be said with certainty that Perkins, to many Bostonians, was a "patron" and had the ability to provide both financial and political

\footnotetext{
${ }^{189}$ Edward Everett to Thomas H. Perkins, 27 December 1826, microfilm box 2, folder 7, Thomas H. Perkins Papers, Massachusetts Historical Society, Boston, MA.

${ }^{190}$ Ibid.
} 
support and approval. It speaks volumes when a United States Congressman has to ask a favor of a wealthy and well-connected private citizen, especially after what seems a strained (although not broken) friendship.

Aside from his political connections and financial influence over prominent individuals, there is also evidence that Perkins had a level of patronage and elitist connection to motivate and influence any person he hired or did business with. Particularly, Perkins seems to have brought certain individuals to financial prominence because he used family, political allies, and business associates to solely do business with these individuals. It was also by that same token that Perkins could punish these individuals if he became displeased by their services. Gilbert Stuart, for instance, painted several times for Perkins and his family and therefore received much business from the Perkins clan. In 1822, Perkins, James' wife, and the Boston Athenaeum commissioned Stuart to produce a painting of James Perkins, Col. Thomas Perkins' brother, who had recently passed away and donated much funds to the Boston Athenaeum. Expecting to see the painting near completion when visiting Stuart, Perkins was angry to find that the painting of his brother was only in sketch form and far from complete. ${ }^{191}$ Perkins stormed out of Stuart's studio yelling "Very well, Mr. Stuart, you have inflicted an irreparable loss by your dilatoriness, and I shall never enter your studio again!"192

A few weeks later, Stuart and Perkins "bumped" into each other and Stuart, expressing great apology, insisted that Perkins come back with him to his studio to see the painting. Although reluctant, Perkins decided to follow the panicked artist.

\footnotetext{
${ }^{191}$ Mabel M. Swan, The Athenaeum Gallery (Boston, MA: Boston Athenaeum, 1940), 4-5. ${ }^{192}$ Ibid.
} 
At the studio, Stuart presented the completed painting to Perkins, what is unusual about this completed painting was the pace in which it was completed. Stuart was known for taking a long time on completing portraits and this painting in particular broke his record for how "quickly" it was completed. ${ }^{193}$ On one hand, Stuart could have completed this portrait so quickly because he did feel bad about James' death and what the portrait meant to Perkins. This may be true, but it seems curious that Stuart would go out of his way to bring Perkins back to his studio after the client had just sworn him off. Could there have been a financial incentive for Stuart's "artistic motivation?"

As it turns out, several of Stuart's clients were Bostonians and many of them were either prominent figures in American society (Washington, the Adams family, etc.) or they were wealthy members of society, many of them connected to Perkins. ${ }^{194}$ These individuals were either related to Perkins, did business with Perkins, were friends with Perkins, or were political allies. These individuals included Israel Thorndike, Thomas Jefferson, Daniel Webster, John Adams, John Quincy Adams, Francis Jackson, John Thornton Kirkland, Henry Rice, Harrison G. Otis, Thomas MacDonough, William Gray, Henry Dearborn, the Quincy family, and several others. ${ }^{195}$ If Stuart felt that losing Perkins' patronage was insignificant, then James' portrait would not have been completed so fast. The fact that Stuart suddenly worked so quickly and went out of his way to make it up to Perkins suggests that Perkins controlled a large

${ }^{193}$ Ibid.

${ }^{194}$ Gilbert-Stuart.org, "The Complete Works," Gilbert Stuart, accessed November 1, 2016, http://www.gilbert-stuart.org/home-2-96-1-0.html

${ }^{195}$ Carl Seaburg and Stanley Patterson, The Merchant Prince of Boston: Colonel T.H. Perkins, 1764-1854 (Cambridge, MA: Harvard University Press, 1971), 140, 217, 381-382. 
section of his income. If we are to accept that all of these other clients went to Stuart based on Perkins' recommendation, then it must mean Perkins could have easily convinced them to boycott Stuart if the artist fell out of his favor. Therefore, not only does this indicate that Stuart's business was shared by a certain section of society, but also that Stuart was, in essence, the client of the Perkins clan and could be rewarded or punished financially based upon the words of a single patron, Col. Thomas Perkins. If Perkins applied the same logic to other businesses and individuals in the Boston area, then it could indicate that most of Boston was subject to the will of a select group of wealthy individuals that were likely lead/controlled by Perkins.

Between politics, business, and family connections, Perkins was connected to local and national politicians. It was with these incentives and various applications of pressure that Perkins established for himself, his friends, and his family a virtual oligarchy and a system of favors in the Commonwealth of Massachusetts. Using this carefully crafted network of connections and financial pressure, Perkins protected his own business interests and gained the attention of national and local politicians to further protect and expand his investments. If Perkins did not have a direct connection to something he wanted, then he became involved in local organizations and political groups. This was for the purpose of expanding his influence and eventually using the organization to gain the favor of the public, or to have the organization act on his behalf (whether directly or indirectly) so as to protect his assets. His influence over Edward Everett in the Greek Committee of Boston is the best example of this. Other organizations that Perkins influenced were the Boston Athenaeum, the Protection 
Committee, the Federalist Central Committee, and The Bunker Hill Monument Committee. ${ }^{196}$

Certainly these efforts gave Perkins much power and protected his immediate assets, it kept the competition at bay and it always ensured Perkins was at the front of the line for any and all government contracts. But why try and expand to national politics? Granted Perkins liked to have one or two people representing him in any major organization, but why did Perkins have several national politicians connected to him during the 1820s in particular (Webster, Everett, Adams, Otis)? The answer lies in the very nature of his business, mercantile trade.

To Perkins, the freedom of traveling the seas was paramount to his business; any war, embargo, or diplomatic faux pas meant disaster or hard times for Perkins' overseas investments. During the War of 1812, Thomas and his brother James described the economic state of affairs as "this most distressing state of things," and "unprofitable."197 Whether or not the war was for a just cause, Perkins viewed any and all disruption as bad and detrimental to his business. It interfered with his ventures and he could not tolerate that at any degree. When one looks into the actual nature of his business by the late $1810 \mathrm{~s}$ and early 1820 s, it is only made obvious that most of his investments have become dependent upon overseas trade, specifically in Canton.

Perkins, by the War of 1812, had established a "home base" in Canton with three non-industrial factories, and his nephew, John Perkins Cushing, was conducting business in Canton on Perkins' behalf. ${ }^{198}$ Initially, Perkins' business in Canton relied upon the sale of furs, specie, and typical European commodities (flour, paper, etc.), but by the mid-

\footnotetext{
${ }^{196}$ Ibid., 168-171, 253, 301, 302, 313-314, 318.

${ }^{197}$ Ibid., 234.

${ }^{198}$ Ibid., 165-166.
} 
1810s these products had lost value. Opium and quicksilver thus became the most attractive alternatives, for they could double Perkins' profits in the region. Perkins, a man always cautious of his investments, jumped at the chance to switch to opium. ${ }^{199}$ If the United States were to go to war or face some sort of embargo, then Perkins would face a sharp drop in profit and an overall economic slump. It only makes sense that Perkins would want to limit these disruptions by having loyal surrogates at the national level.

It must also be noted that Perkins and his associates were by no means pacifists and at times even welcomed conflict in other countries. During the Napoleonic Wars, Perkins joined the Higginsons (related by several marriages) in transporting and selling flour to British troops in Spain at marked up prices. ${ }^{200}$ Furthermore, Perkins even floated the idea of taking advantage of the Spanish Empire's fragmented state and getting into trade with the newly forming South American Republics. ${ }^{201}$ While nothing immediately came of the prospects in Latin America, the Perkins and the Higginsons had invested wholeheartedly into the flour trade in Spain and were even smuggling the cargo past the French blockade. ${ }^{202}$ Thus, Perkins favored not a peaceful economy, but rather a "neutral" economy. Perkins wanted the United States out of foreign affairs and his own ships capable of reaching and trading with any port, for if there was a foreign war, he was willing to exploit it.

${ }^{199}$ Ibid., 265 and 285.

${ }^{200}$ W. Richard T. Hackley to Thomas H. Perkins, 22 March 1811, microfilm reel 12, volume 53, Thomas H. Perkins Papers, Massachusetts Historical Society, Boston, MA.; Thomas H.

Perkins to M.R.T. Hackley(?), 22 March 1811, microfilm reel 12, volume 53, Thomas H. Perkins Papers, Massachusetts Historical Society, Boston, MA.

${ }^{201}$ Carl Seaburg and Stanley Patterson, The Merchant Prince of Boston: Colonel T.H. Perkins, 1764-1854 (Cambridge, MA: Harvard University Press, 1971), 220.

${ }^{202}$ Ibid., 222. 
The reason he wanted a "neutral" and "free trade" economy was because he both feared and experienced years where his ships were limited in their commerce capabilities because of either an embargo or ongoing conflict. His first brush with economic frustration came with the Embargo of 1807. While the United States was at peace, the government was technically not neutral and this severely limited mercantile prospects. Perkins had to accept economic uncertainty and ordered John Perkins Cushing to stay "out of danger till the storm blows over" and essentially to batten down the hatches if communication was cut off. ${ }^{203}$ Furthermore, James and Col. Thomas Perkins seemed to become increasingly cynical as the situation deteriorated and feared that the already limited trading prospects would become worse if Jefferson might plunge the country "into a Contest which would be ruinous and to defend a principle not worth a Cent to us. ${ }^{204}$ Perkins did not care about the diplomacy of the situation, he only cared about how it affected his business, and, in his mind, Jefferson was meddlesome and foolish. When both the French and British began to seize American ships, and Jefferson ordered American ships to stay home, it struck a blow against Perkins' business, as he was powerless to communicate with his surrogates in Canton and Europe, and was thus left unable to continue his affairs in a comprehensive sense. ${ }^{205}$

While the Embargo did stunt much of Perkins' business, he was not completely disadvantaged. He still had a few ships abroad, and the British and French would allow American ships to return home. Seizing the opportunity, Perkins ordered both Cushing and his remaining vessels to stay in their foreign ports and conduct business at the local

${ }^{203}$ Ibid., 186.

${ }^{204}$ Thomas and James Perkins, Foreign Letter Book, August 1, September 25, October 22, November 11, and November 19, 1807, microfilm reel 12, volume 53, Thomas H. Perkins Papers, Massachusetts Historical Society, Boston, MA.

${ }^{205}$ Seaburg, The Merchant Prince, 187. 
level. Fortunately for Cushing, this meant he could still sail to the American Northwest since it was less affected by the Embargo, and trade furs with the Russians and the Chinese. ${ }^{206}$ This managed to keep Perkins afloat while he explored other ventures in light of this new economic landscape.

Another period of uncertainty for Perkins was the War of 1812; again, Perkins was unable to communicate with his foreign ports and had to seek other prospects for the time being. Perkins sent his nephew, Frederick Paine, with a list of instructions and to assist John Cushing in the Canton trade. ${ }^{207}$ Since Perkins could no longer communicate with his ships abroad, he decided to take a risk and focus on his iron trade in Vergennes, VT. Firing Theophilus Bradbury, Perkins and his partners took on direct management of the iron business and sought to continue their income until the War of 1812 was finished. ${ }^{208}$ Looking to get some return on this unusual economic situation, Perkins decided to sell cannon balls to the United States Navy at heavily marked up prices. Specifically, he sold the iron at $\$ 120$ per ton when it only cost him $\$ 25$ per ton to mine and cast the iron. ${ }^{209}$

To Perkins, the situation was far from ideal as the iron business had proven to be only marginally profitable since the beginning of the War. Thus, it can be safely assumed that Perkins wanted the war over as soon as possible and for his business in Canton to continue immediately. Perkins, being a state representative at the time, organized and helped commission a report that would both discredit Madison's justification for the war (impressment), and take testimony from the merchant community of Boston, which

\footnotetext{
${ }^{206}$ Ibid., 189-190.

${ }^{207}$ Ibid., 236.

${ }^{208}$ Ibid., 236-238.

${ }^{209}$ James Elliot Cabot, Extracts from Letterbooks of J \& T H Perkins et al. (1886), 211-213.; Seaburg, The Merchant Prince, 238.
} 
meant interviewing himself and his Federalist merchant associates. ${ }^{210}$ In both James' and Thomas' testimonies, they maintained that cases of impressment for his sailors were merely a handful and most of those impressed were foreigners. ${ }^{211}$ Whether or not the evidence present by the committee is true, it demonstrates two very important facts about Col. Thomas Perkins. First, Perkins was willing to use his own authority as an elected representative to essentially benefit himself by not only generating an investigation that would help his business, but also using the testimonies of himself, his friends, his family, and business associates as evidence. Second, Perkins despised any and all economic uncertainty, he did not truly care about the war or foreign issues, he only wanted his business to go unhindered and to craft economic conditions favorable to his business.

As the conflict dragged on, Perkins became evermore impatient with his current predicament and decided to take stronger political action. In 1814 and 1815, Perkins decided to help organize the New England Secessionist movement and put into action a plan that would free Massachusetts and other states from the Union. Perkins became so involved in this movement that he was selected to be one of the three agents (the others being H.G. Otis and William Sullivan) to present the case for secession before the federal government in Washington D.C. ${ }^{212}$ The New England Secessionist movement failed because when Perkins and the others arrived in Washington the war had ended and their justification for leaving the Union had lost validity. This incident in Perkins' life demonstrates that he was not really dedicated to any ideology or real political cause. On one hand, he sold munitions to the United States for the war effort, and, on the other

${ }^{210}$ Seaburg, The Merchant Prince, 238-239.

${ }^{211}$ Massachusetts General Court House of Representatives, Report of the Committee of the House of Representatives of Massachusetts, on the Subject of Impressed Seamen (Boston, MA: Russell \& Cutler, 1813), 44-46.

${ }^{212}$ Seaburg, The Merchant Prince, 255-260. 
hand, he openly detested the conflict and actively organized to break from the Union. In some years he would praise the President and host a parade for the visiting politician, and in other years he was willing to mock every word of the President and threaten to secede from the Union. Perkins did not follow a political cause because he actually believed in it, but rather he used political events to benefit his business. If ensuring his overseas trade would continue unhindered required seceding from the United States, then he would not even bat an eye and secede wholeheartedly.

The War of 1812 and the Embargo of 1807 are significant because they pushed Perkins to explore all of his options when he was cut off from his foreign investments. Perkins tried his hand at the domestic industry and attempted to create a foreign trade network that could operate somewhat independently until the crises had passed. As Perkins learned, this was easier said than done and his return on investment tended to be far less than what he would make from the Canton Trade. In the War of 1812, Perkins tried to do something new, he attempted to affect the national government and essentially dictate United States foreign policy. His contribution to the New England Secession movement and the Massachusetts General Court House of Representatives Investigation Committee demonstrate this clear attempt to affect the national stage. Their ultimate failure in stopping the war only proved to Perkins that he needed to have a much more significant influence on the national stage. Whether it was through surrogates or campaigning for office himself, Perkins knew that he needed to influence the federal government in a much more direct way to protect his investments, The Greek War for Independence demonstrates the success of his ultimate plan. 
Thomas H. Perkins, after recovering from the War of 1812, began to feel increasingly deeper incentives to influence the federal government as the Era of Good Feelings began to reveal potential problems. In 1815, eager to rebuild his funds, Perkins switched most of his business to the Opium Trade as it promised to double his profit and create a reliable market through the selling of Turkish opium to addicted Chinese people living in the Northern Provinces of China. ${ }^{213}$ Perkins still maintained a presence in the American Northwest and the Canton Fur Trade, but there was an intensification in competition as Russian fur traders moved into the Northwest region. ${ }^{214}$ In 1818 Perkins became even more invested in the Opium Trade as the Co-Hong trading guild suffered a major fine from the Chinese government for participating in the Opium Trade. As a result, competition in the Opium Trade decreased and this allowed Perkins to enter the market with a lowered price and the ability to make a long-lasting impact on the market. ${ }^{215}$ While Perkins' operations were small compared to the British, he could use his factories and offshore ships to deal with the Chinese people directly. Selling up to 100,000 pounds of opium, Perkins could store the drug in his vessels, drop off the product to purchases passing by in smaller vessels while the factories on shore would communicate with the purchasers and collect the money. ${ }^{216}$ This less competitive system made it easier for Perkins to focus on the Opium Trade and the Canton market, thus investing himself progressively more into the practice.

Another incentive that pushed Perkins more firmly into the Opium Trade was the recent passage of tariffs on cotton caused by the Compromise of 1820 . Otis, who had

${ }^{213}$ Ibid., 265-267.

${ }^{214}$ Ibid., 267-268.

${ }^{215}$ Ibid., 284-285.

${ }^{216}$ James Elliot Cabot, Extracts from Letterbooks of J \& T H Perkins et al. (1886), 249-260.; Seaburg, The Merchant Prince, 285. 
fought against the increase in tariffs, informed Perkins that the tariffs would hurt any merchants that built their fortune on foreign trade. ${ }^{217}$ While Boston was secure and it would not increase its own tariffs, New York City had approved the increase and, as the leading commercial center of the country, many of the other American ports would reflect this policy therefore making it difficult overall for those involved in commerce. ${ }^{218}$ Thus, the cotton market was becoming problematic for Perkins and might have encouraged the merchant to participate less in that particular trade and instead focus his efforts in Canton.

In 1820 an 1821 , Perkins only became more eager to invest in the opium trade as he and Cushing realized that they had cornered a section of the market. The Chinese in the Northern Provinces preferred exclusively Turkish opium, the British and other European traders were selling Bengalese and Indian opium, and these types did not appeal to that part of the market. Fortunately for Perkins, he was only one of a handful of merchants that had access to the Turkish strain of opium. Perkins and Cushing had enough of the opium warehoused that they could control the market and sell the product strategically at the highest price. ${ }^{219}$ This part of the market was so profitable and safe for Perkins that he was able to purchase opium from Turkey at $\$ 2.50$ a pound and sell it for more than 3 to 4 times as much (\$7 to $\$ 10$ a pound). ${ }^{220}$ Thus it was only to Perkins' advantage to keep himself in the Turkish opium sector of the market because he had very little competition, he could make an astronomical profit, and he could control the market.

${ }^{217}$ H.G. Otis to T.H. Perkins, 22 April 1820, microfilm reel 7, Otis Papers, Massachusetts Historical Society, Boston, MA.

${ }^{218}$ Seaburg, The Merchant Prince, 294-295.

${ }^{219}$ Perkins \& Co., Canton Letterbook, 27 March 1820, letterbook volume 19, Baker Library Historical Collection, Harvard Business School, Boston, MA.

${ }^{220}$ Seaburg, The Merchant Prince, 297-298. 
If he were to try and enter the Bengal or Indian opium market, he would have to deal with the British, who could raise their prices at any time, and the South Asian type of opium was so common that Perkins would constantly be faced with competition and there would be only a small margin of profit.

After this reaffirmation into the Canton trade, Perkins and his family decided to formally withdraw from the Northwest Fur Trade. The Northwest Company no longer saw the venture as mutually profitable, and furs in China had drastically decreased in value over the years. ${ }^{221}$ Additionally, James and Thomas, in 1821, decided to change the management of the organization by incorporating their sons as co-owners of the company. ${ }^{222}$ Thus, in 1821 , the entirety of the business rested upon the Opium Trade and the good will of the Turks, this being just before the beginning of the Greek War for Independence. While 1821 might have seemed like a good year for the Perkins firm, 1822 would existentially threaten the very structure of Thomas' business.

On August 1, 1822, James Perkins, Thomas' most trusted business partner and brother, died and left Thomas to manage a business that went half-way around the world. ${ }^{223}$ A few months later in March 1823, Perkins received word that his Canton factories had caught fire and were burnt to the ground in November of $1822 .{ }^{224}$ Aside from the factories burning down, $\$ 20,000$ worth of specie was plundered in the confusion and the merchandise in the factories was lost. Fortunately, the merchandise's value was "trifle" and most of the books and papers concerning their business were saved. ${ }^{225}$ While

\footnotetext{
${ }^{221}$ Ibid., 300-301.

${ }^{222}$ James Elliot Cabot, Extracts from Letterbooks of J \& T H Perkins et al. (1886), 307.

${ }^{223}$ Seaburg, The Merchant Prince, 301-302.

${ }^{224}$ Perkins \& Co., Canton Letterbook, 7 November 1822, letterbook volume 20, Baker Library Historical Collection, Harvard Business School, Boston, MA.

${ }^{225}$ Seaburg, The Merchant Prince, 308-309.
} 
the fire was not a complete disaster, it did require a substantial reinvestment of funds, and Perkins needed to go to London in order to secure woolen cloth cargo so as to beat the British in re-establishing their foothold in the Canton market. ${ }^{226}$ Late 1822 and early 1823 proved to be trying times for Perkins' business, he was now completely investing into Canton opium with very few alternative commodities, he had lost his brother and business partner, and had just lost a substantial holding in Canton due to a fire. Furthermore, Perkins' opium supply was a niche market that had little competition, switching to any alternative would be financially damaging. As Seaburg and Patterson explain, Perkins investment in the opium trade relied entirely upon the good will and inclination of the Ottoman Empire to do business with Perkins. ${ }^{227}$ Not to mention, Perkins had just switched over part of the management of the company to the Cabots and his son, T.H. Perkins Jr., both of whom were relatively new to trade in Canton.

In 1823, as the Greek War for Independence started to intensify and the American public began to show growing support for the Greek cause, Perkins began to realize how fragile his situation was. The misfortunes of the past year could be dealt with easily as long as the Turks were still interested in trading. If the United States went to war with Turkey or even just embargoed the Turks, then it would be an utter disaster for Perkins' business and, even once the conflict had ended, Perkins might have to withdraw from Canton completely. Fortunately, Perkins had prepared for this situation and had learned from his misfortunes during the War of 1812 and the Embargo of 1807. Using his political network in Massachusetts, his business ties, and the influence he had over key politicians, Col. Thomas Perkins was able to infiltrate the federal government with loyal

\footnotetext{
${ }^{226}$ Ibid., 309.

${ }^{227}$ Ibid., 313.
} 
surrogates and ultimately influence U.S. foreign policy, not just for the Greek conflict, but also for the rest of the $19^{\text {th }}$ Century.

Perkins was not unfamiliar with influencing national politicians, although it had been limited to one or two individuals in the past, he knew how to extend his influence beyond the Hudson River. Harrison G. Otis served as Massachusetts' Senator and Congressman and was an active leader in Massachusetts politics, he was also a close friend, political ally, business partner, and relative of Thomas H. Perkins. ${ }^{228}$ Otis was also a Blue Light Federalist, attended the Hartford Convention, and traveled with Perkins to Washington at the end of the war. Perkins knew how to place people in power and already had close friends legislating for him on the national level.

The Federalist roots of Col. Thomas Perkins also helped him rub elbows with some of America's most influential and historical leaders, particularly, John Adams. In a letter concerning a gift of grapes, John Adams thanked Perkins and recalled their longtime friendship. ${ }^{229}$ This demonstrates a somewhat personal relationship that went beyond simple professional formalities. Perkins also helped lead a parade in John Adams' honor and formed a mutually respectful relationship from this occasion. ${ }^{230}$ At the beginning of the 1807 Embargo, both Perkins and Adams presided over the Federalist Party Committee in Fanueil Hall, demonstrating (at least) a professional relationship where they both organized party events together. ${ }^{231}$ Furthermore, aside from their political commonalities, both were co-investors in a Boston theater and, thus, were business

${ }^{228}$ Ibid., 170, 186, 31-32, 256, 294.

${ }^{229}$ John Adams to Thomas H. Perkins, 16 September 1825, microfilm reel 2, volume 5, Thomas H. Perkins Papers, Massachusetts Historical Society, Boston, MA.

${ }^{230}$ Seaburg, The Merchant Prince, 125-127.

${ }^{231}$ Ibid., 185. 
associates. ${ }^{232}$ Col. Thomas Perkins and John Adams Sr. knew each other and, by all accounts, seemed to have a friendly relationship that gave Perkins clout amongst the Federalist Party and some influence over Adams' son, John Quincy Adams.

John Quincy Adams, as mentioned earlier in this section, had to contend with Perkins for most of his political career. Using a stick and carrot method to whip Adams into line, Perkins seemed to have a rather complicated relationship with America's sixth president. Perkins, being a member of the Federalist Central Committee, signed off on every politician that was elected to a Massachusetts public office, Adams, undoubtedly, was introduced to Perkins in this way or through his father. ${ }^{233}$ Perhaps John Quincy Adams first entered this relationship of reward and punishment through the "election" process, he owed Perkins for his position in some way and would "fall in line" when he was asked. Whether or not such a system was formally in place, one can only speculate. Though, it is curious that Adams' political and social ostracism as well as prevention from taking public office in 1808 was directly attributed to his half-approval of the 1807 Embargo. What is more interesting was Perkins' central role in preventing Adams from being elected to office. ${ }^{234}$ Despite this checkered past, Perkins and Adams saw each other frequently and had to deal with each other politically on an everyday basis. ${ }^{235}$

That being said, there must have been some sort of understanding or agreement between Perkins and Adams to communicate on a regular basis and work so hard for the other. For instance, Perkins was opposed to the Greek War for Independence because it

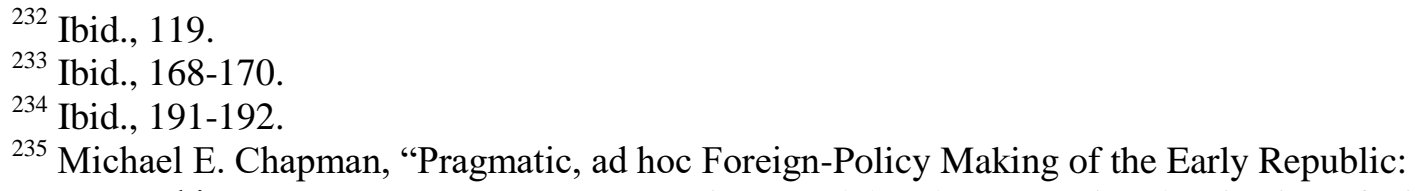

${ }^{235}$ Michael E. Chapman, "Pragmatic, ad hoc Foreign-Policy Making of the Early Republic: Thomas H. Perkins's Boston-Smyrna-Canton Opium Model and Congressional Rejection of Aid for Greek Independence," International History Review 35, no. 3 (2013): 455. 
threatened his business and, coincidently, John Quincy Adams proved to be one of the strongest opponents to the war, both as the United States Secretary of State and as the President of the United States. ${ }^{236}$ Adams, oddly enough, also advocated for a "Most Favored Nation" status with the Ottoman Empire, this agreement essentially secured Perkins' assets indefinitely and made sure the Opium Trade could continue. ${ }^{237}$

Adams, as it turned out, was financially tied to Perkins and his associates during the Greek War for Independence. In a letter from 1827, Adams thanked Perkins for his business advice and getting him stocks in a factory with Israel Thorndike. ${ }^{238}$

Furthermore, Perkins was initially an ardent support of John Quincy Adams for his 1828 bid for the presidency. Using his political connections, funds, and the network he had in Massachusetts, Perkins was able to give Adams a running start. ${ }^{239}$

Politics, as it would be, stirred up scandal for Adams as his connections to Perkins and the Federalist Party ended up landing the President into some hot water. Stemming from a letter written by Thomas Jefferson, the issue of the Hartford Convention and the New England Secession movement called into question Adams' loyalties and connections to the Federalist Party. Adams foolishly tried to explain away the events and, essentially, accused the Federalist of being traitors that were in league with the British. ${ }^{240}$ Perkins, to say the least, did not approve of this and he, as well as other politicians such as Otis, stepped forward questioning Adams' comments. This lead to a publication war in the newspaper between Adams and Perkins' alias, A Merchant,

${ }^{236}$ Ibid., 451-452.

${ }^{237}$ Ibid., 460-461.

${ }^{238}$ John Quincy Adams to Col. Thomas Handasyd Perkins, 3 October 1827, microfilm roll 2, folder 7, Thomas H. Perkins Papers, Massachusetts Historical Society, Boston, MA.

${ }^{239}$ Carl Seaburg and Stanley Patterson, The Merchant Prince of Boston: Colonel T.H. Perkins, 1764-1854 (Cambridge, MA: Harvard University Press, 1971), 350-351.

${ }^{240}$ Ibid., 351-352. 
while it rustled feathers and put Adams into a rather awkward situation, the incident did not help Adams in the election at all. ${ }^{241}$ Perkins withdrew his support and Jackson made fast work of Adams' faux pas in the newspaper. Needless to say, Adams was not reelected. $^{242}$

Whether or not Perkins and Adams were friendly, it is almost certain that the two knew each other for most their political careers. Perkins seemed to have some sort of influence over Adams whenever he was in office and there was some sort of reward and punishment between the two men. Perkins pulled Adams into his influence both politically and financially. With Adams under his influence, Perkins was able to use Adams' position in the federal government to protect his own interests.

The other unfortunate figure that fell under Perkins' influence was Edward Everett, a passionate supporter of the Greek War for Independence, was also caught up in a similar reward and punishment situation. As previously mentioned, Perkins and Everett were both members of the Boston Greek Committee and Everett, after being elected to the United States House of Representatives, was in dire financial straights and asked Perkins for his financial support in the conflict. ${ }^{243}$ Perkins also used his influence to deter Everett at the beginning of the conflict by writing anonymous letters to the local newspaper counterpointing the articles published by Everett and the committee. ${ }^{244}$ Despite this odd relationship of both opposing and somewhat supporting each other, Everett and Perkins also shared a financial and professional relationship with several

${ }^{241}$ Ibid., 352-355.

${ }^{242}$ Ibid.

${ }^{243}$ Edward Everett to Thomas H. Perkins, 27 December 1826, microfilm box 2, folder 7, Thomas H. Perkins Papers, Massachusetts Historical Society, Boston, MA.

${ }^{244}$ Carl Seaburg and Stanley Patterson, The Merchant Prince of Boston: Colonel T.H. Perkins, 1764-1854 (Cambridge, MA: Harvard University Press, 1971), 313-314. 
different projects. For instance, both men organized the Bunker Hill Monument Association and worked closely together. ${ }^{245}$

Everett was also connected financially to Perkins through his brother Alexander Everett. Alexander, also a friend and business associate of John Quincy Adams, had conducted some business with Perkins and he was also a friend through Perkins' daughter Eliza. ${ }^{246}$ Perkins also dealt with Edward Everett directly in politics. When Perkins began to organize the re-election campaign for John Quincy Adams, Perkins called upon Everett and Daniel Webster to help draw up the plans. ${ }^{247}$ Thus, Everett was within Perkins' sphere of influence and, at the very least, Everett was obligated to Perkins because of his political prominence in the state, as well as the mixed financial support Everett needed and Perkins could provide for the Greek War of Independence. Thus, despite the support Everett had for the Greeks, Perkins more than likely "changed his mind" on this issue by using his political and financial influence. Simultaneously, Perkins might have also used his influence with the wealthy Boston merchant community to prevent donations from reaching the Greek Committee of Boston. Much like the affair with Gilbert Stuart, Perkins more than likely convinced his wealthy peers to withhold their donations to the Greek Committee of Boston, or at least threatened Everett that he might do so. Thus, this put Everett in a position where he had to water-down his rhetoric on the cause so as to gather and send any funds to Greece.

Daniel Webster also fell well within this sphere of influence due to his friendship with not only Perkins, but also with several of Perkins' business associates. Israel

${ }^{245}$ Ibid., 319.; George Washington Warren, The History of the Bunker Hill Monument Association (Boston, MA: James R. Osgood Co., 1877), 103.

${ }^{246}$ Carl Seaburg and Stanley Patterson, The Merchant Prince of Boston: Colonel T.H. Perkins, 1764-1854 (Cambridge, MA: Harvard University Press, 1971), 222-223.

${ }^{247}$ Ibid., 350-352. 
Thorndike, one of the wealthiest people in the Commonwealth of Massachusetts at the time, had conducted business several times with Perkins both in Canton and on local prospects. Thorndike was also one of Perkins' oldest friends and had often invested in projects together for mutual benefit, some of the most noteworthy investments they shared in were the (now) McLean Hospital, the Massachusetts Cape Cod Grand Canal, Nahant Hotel, and the Bunker Hill Monument. ${ }^{248}$ Interestingly, Webster was also a participant in the Bunker Hill Monument project and was a very friendly neighbor of Israel Thorndike. ${ }^{249}$ So close were these two individuals that, in fact, they had a door cut between their houses so they could both host larger parties together and socialize together more often. ${ }^{250}$ Webster, aside from being in debt to Perkins at a time, had been a close friend through their mutual relationship with Thorndike and, too, worked on the Bunker Hill Monument project together. ${ }^{251}$ In addition, having had a long political career in Boston, it is impossible that Webster would not have had to know Perkins in order to achieve the public offices he held during his career. Thus, Webster was not only an individual that fell directly under Perkins' influence, but also was more than likely a very friendly acquaintance that often shared in Perkins' business dealings.

Considering all the connections, investments, relations, and political presence Col. Thomas H. Perkins had in the Commonwealth of Massachusetts, it is evident that this individual had some of the greatest influence on the Early Republic in American history. Furthermore, his investments, dealings, and involvement in the Canton Opium

\footnotetext{
${ }^{248}$ Ibid., 283, 284, 309-310.; George Washington Warren, The History of the Bunker Hill Monument Association (Boston, MA: James R. Osgood Co., 1877), 103.

${ }^{249}$ Carl Seaburg and Stanley Patterson, The Merchant Prince of Boston: Colonel T.H. Perkins, 1764-1854 (Cambridge, MA: Harvard University Press, 1971), 318-320.

${ }^{250}$ Ibid., 326.

${ }^{251}$ Ibid., 341-342.
} 
Trade prove to be the greatest motivator for Col. Perkins' actions in politics, business, and American society in general. His connections to national politicians, such as Edward Everett, Daniel Webster, John Quincy Adams, James Monroe, and Harrison G. Otis, demonstrate an unusual amount of political and financial influence that cannot be ignored by American historians. Thus, when studying America's involvement in the Greek War for Independence, it is impossible to attribute America's decision to remain neutral to actual diplomatic considerations that were in the interest of the country. Rather, it is more likely that America's neutrality was caused by Col. Thomas H. Perkins since the people who ended up creating the act of neutrality both knew Col. Thomas Perkins for a large part of their lives and were obligated to Perkins' interests out of friendship, political patronage, or mutually shared financial stakes. 


\section{Conclusion}

During the first years of the Early American Republic, the American people were faced with a diplomatic crisis that tested the very identity of American culture and values. As Greece struggled for independence during the 1820s, several European powers rushed to aid the Greeks in their cause for independence. Inspired by their mutual love of liberty, a common faith in Christianity, and an admiration of the Ancient World, Americans in all levels of society clamored to aid in the Greek Revolution. It was through private donation, political organization, and volunteerism that regular Americans eagerly demanded a formal presence in the Greek War for Independence.

Despite the endorsement of prominent individuals, such as Thomas Jefferson, Edward Everett, and Henry Clay, the United States government chose not to become involved in the Greek War for Independence. Formally excusing itself on the basis of the Monroe Doctrine and an uncomfortable association with the British, the United States government crafted a foreign policy of diplomatic neutrality that would last the entirety of the $19^{\text {th }}$ Century. Despite the seemingly legitimate pardoning from the conflict, inconsistencies in political rhetoric and action reveal a deeper and more sinister truth behind America's neutrality.

The political, social, and financial association that Edward Everett, James Monroe, Daniel Webster, and John Quincy Adams had with the Boston merchant Col. Thomas H. Perkins and his comrades reveals a shocking and corrupt-laden tale about the events surrounding America's neutrality in the Greek War for Independence. Perkins, looking out for only his business investments, used his political monopoly in 
Massachusetts and finances to influence and control politicians at the federal level. Fearing for his dependence on the opium market in the Ottoman Empire, Perkins made certain that both the Congress and the President of the United States not only avoid any bad relations with the Ottoman Empire, but also made sure to strengthen its current economic ties. Thus, through the orders and interests of Thomas H. Perkins and the merchant community, the United States government chose to relinquish any and all formal interest in the Greek War for Independence. Therefore, the government turned against both the will of the American people and the principles of Liberalism, Republicanism, and Classicism in which the nation was founded upon. Thus, the United States government not only chose a stance of neutrality that only a select group of people benefitted from, but also set the precedence for American foreign policy for the rest of the $19^{\text {th }}$ Century. 


\section{Bibliography}

\section{Primary Sources Bibliography}

$18^{\text {th }}$ Congress of the United States. "Debates and Proceedings, 1789-1824." Annals of Congress, from A Century of Law Making for a New Nation. Accessed November 26, 2016. http://memory.loc.gov/cgi-bin/ampage

Account Book. 25 January 1803. microfilm reel 5, volume 33, Thomas Handasyd Perkins Papers, E. Bumstead \& Co. Massachusetts Historical Society, Boston, MA.

Adams, John. Letter to Thomas H. Perkins. Thomas H. Perkins Papers. Massachusetts Historical Society, Boston, MA.

Adams, John Quincy. Letter to Col. Thomas Handasyd Perkins. Thomas H. Perkins Papers. Massachusetts Historical Society, Boston, MA.

Cabot, James Elliot. Extracts from Letterbooks of J \& T H Perkins et al. 1886.

Carpenter, Willett. “Ran Away.” Newport Mercury, September 24, 1799.

Dwight, Sereno Edwards. The Greek Revolution: An Address, delivered in Park Street Church, Boston. Boston, MA: Crocker and Brewster, 1824.

Everett, Edward. "The Character of Quincy Adams.” Orations and Speeches. Bartlby.com, 1848. http://www.bartleby.com/400/prose/949.html

Everett, Edward. Letter to Col. Thomas H. Perkins. Thomas Handasyd Perkins Papers. Massachusetts Historical Society, Boston, MA.

Garrett, Alex. Deed, 1813, of Thomas Jefferson, "Monticello," Albemarle County, Va., to his grandson Thomas Jefferson Randolph, "Monticello, " Albemarle County, Va., for African-American slaves (March 26, 1813). Virginia Historical Society, accessed on March 1, 2017, http://unknownnolonger.vahistorical.org/record/824/89\#

Gore, Christopher. Letter to Rufus King, 16 June 1808. Rufus King Papers. New York Historical Society, New York.

Hackley, W. Richard T. Letter to Thomas H. Perkins. Thomas H. Perkins Papers. Massachusetts Historical Society, Boston, MA.

Jenkins, Richard. “Run Away.” New York Gazette, April 22, 1782. 
Lloyd, Thomas George Caines, and The Massachusetts Supreme Judicial Court. The Trial of Thomas 0 . Selfridge, attorney at law, before the Honorable Isaac Parker, Esquire. For Killing Charles Austin, On the Public Exchange, in Boston, August 4, 1806. Boston MA: Russell and Cutler, 1807.

Lyman, Theodore. "Statement of Facts." Columbian Centinel, May 14, 1796.

Massachusetts General Court House of Representatives. Report of the Committee of the House of Representatives of Massachusetts, on the Subject of Impressed Seamen. Boston, MA: Russell \& Cutler, 1813.

Miller, J.P. and George Jarvis. Letters from Greece. Providence, RI: Boston University, 1825.

Monroe, James. "Seventh Annual Message (Monroe Doctrine) (December 2, 1823)." Miller Center of the University of Virginia. Charlottesville, VA: University of Virginia website, 2016.

http://millercenter.org/president/monroe/speeches/speech-3604

Otis, Harrison G. Letter to Thomas H. Perkins. Otis Papers. Massachusetts Historical Society, Boston, MA.

Otis, Harrison G. Letter to Woodbury Storer. Miscellaneous Bound Papers. Massachusetts Historical Society, Boston, MA.

Perkins, Thomas H. Letter to M.R.T. Hackley. Thomas H. Perkins Papers. Massachusetts Historical Society, Boston, MA.

Perkins, Thomas H. and James Perkins. Foreign Letter Book. Thomas H. Perkins Papers. Massachusetts Historical Society, Boston, MA.

Perkins \& Co. Canton Letterbook. Baker Library Historical Collection. Harvard Business School, Boston, MA.

Quincy, Eliza Susan. Diaries. 6 July 1817. Quincy, Wendell, Holmes \& Upham Family Papers. Massachusetts Historical Society, Boston, MA.

Robinson, David M. America in Greece: A Traditional Policy. New York: Anatolia Press, 1948.

Rodgers, John. Letter to Henry Clay. Dispatches from U.S. Ministers to Turkey, 18181906. National Archives, Waltham, MA.

Savage, James. Letters of James Savage to his Family: 1784-1873. Boston, MA: Privately Printed, 1906. 
Washington, George, and John Parke Custis. Inventory, ca. 1759, of African American slaves belonging to George Washington, and John Parke Custis through the estate of Daniel Parke Custis. (1759). Virginia Historical Society, accessed on March 1, 2017 from http://unknownnolonger.vahistorical.org/record/12114/697

Webster, Daniel. Mr. Webster's Speech on the Greek Revolution. Boston: Cummings, Hilliard, \& Co. University Press, 1824.

White, Aaron. Diaries. 2 July 1817. Massachusetts Historical Society, Boston, MA.

Winthrop, Robert, Robert Winthrop Jr., Charles Dean, Edward Hale, and George Ellis. "March Meeting, 1880. Letter from Joseph Dennie, Jr." Proceedings of the Massachusetts Historical Society 17 (1879-1880): 360-467. 


\section{Secondary Sources Bibliography}

American-Rails.com. "The Granite Railway, First Chartered Railroad." Railroad History. Accessed November 27, 2016. http://www.american-rails.com/graniterailway.html

Cartledge, Paul. "Ancient Sparta in Modern Fiction." History Today 65, no. 8 (August 2015). Accessed October 16, 2016. http://www.historytoday.com/paulcartledge/ancient-sparta-modern-fiction

Chapman, Michael E. "Pragmatic, ad hoc Foreign-Policy Making of the Early Republic: Thomas H. Perkins's Boston-Smyrna-Canton Opium Model and Congressional Rejection of Aid for Greek Independence." International History Review 35, no. 3 (2013): 449-464.

Earle, Edward Meade. "American Interest in the Greek Cause, 1821-1827." The American Historical Review 33, no. 1 (1927): 44-63.

Forbes, J.D. Israel Thorndike, Federalist Financier. New York, NY: Exposition Press, 1953.

Gilbert-Stuart.org. "The Complete Works." Gilbert Stuart. Accessed November 1, 2016. http://www.gilbert-stuart.org/home-2-96-1-0.html

Horton, Andrew S. "Jefferson and Korais: The American Revolution and the Greek Constitution." Comparative Literature Studies 13, no. 4 (December 1976): 323329.

Kaplan, Lawrence S. "The Monroe Doctrine and the Truman Doctrine: The Case of Greece." Journal of the Early Republic 13, no. 1 (Spring 1993): 1-21.

Kolchin, Peter. American Slavery: 1619-1877. New York, NY: Hill and Wang, 2003.

Lankford, Nelson. "About this Project." Unknown No Longer: Virginia Historical Society. Accessed March 1, 2017.

http://unknownnolonger.vahistorical.org/about-this-project

Repousis, Angelo. “The Cause of the Greeks': Philadelphia and the Greek War for Independence, 1821-1828." The Pennsylvania Magazine of History and Biography 123, no. 4 (October 1999): 333-363.

Richard, Carl J. The Founders and the Classics: Greece, Rome, and the American Enlightenment. Cambridge, Massachusetts: Harvard University Press, 1994. 
Richard, Carl J. The Golden Age of the Classics in America: Greece, Rome, and the Antebellum United States. Cambridge, Massachusetts: Harvard University Press, 2009.

Said, Edward W. "Knowing the Oriental." In Readings for a History of Anthropological Theory, edited by Paul A. Erikson and Liam D. Murphy, locations 13532-14011. Toronto, ON: University of Toronto Press, 2017. Kindle edition.

Seaburg, Carl, and Stanley Paterson. Merchant Prince of Boston: Colonel T.H. Perkins, 1764-1854. Cambridge, Massachusetts: Harvard University Press, 1971.

Swan, Mabel M. The Athenaeum Gallery. Boston, MA: Boston Athenaeum, 1940.

Walton, E.P. Records of Governor and Council of the State of Vermont. Vol. VIII. Montpelier, VT: Steam Press of Joseph Poland, 1880.

Warren, George Washington. The History of the Bunker Hill Monument Association. Boston, MA: James R. Osgood Co., 1877. 